\title{
Experimental and Theoretical Investigations of the Loss of Amino Acid Side Chains in Electron Capture Dissociation of Model Peptides
}

\author{
Y. M. Eva Fung and T.-W. Dominic Chan \\ Department of Chemistry, The Chinese University of Hong Kong, Shatin, Hong Kong SAR, China
}

Loss of side chains from different amino acid residues in a model peptide framework of RGGGXGGGR under electron capture dissociation conditions were systematically investigated, where $\mathrm{X}$ represents one of the twenty common amino acid residues. The $\alpha$-carbon radical cations initially formed by $\mathrm{N}-\mathrm{C}_{\alpha}$ cleavage of peptide ions were shown to undergo secondary dissociation through losses of even-electron and/or odd-electron side-chain moieties. Among the twenty common amino acid residues studied, thirteen of them were found to lose their characteristic side chains in terms of odd-electron neutral fragments, and nine of them were found to lose even-electron neutral side chains. Several generalized dissociation pathways were proposed and were evaluated theoretically with truncated leucine-containing models using ab initio calculations at B3-PMP2/6-311 ++ G(3df,2p)//B3LYP/6-31 + + G(d,p) level. Elimination of odd-electron side chain was associated with the initial abstraction of the hydrogen from the $\alpha$-carbon bearing the side chain by the $\mathrm{N}$-terminal $\alpha$-carbon radical. Subsequent formation of $\alpha-\beta$ carbon-carbon double bond leads to the elimination of the odd-electron side chain. The energy barrier for this reaction pathway was $89 \mathrm{kJmol}^{-1}$. This reaction pathway was $111 \mathrm{kJmol}^{-1}$ more favorable than the previously proposed pathway involving the formation of cyclic lactam. Elimination of even-electron side chain was associated with the initial abstraction of the $\gamma$-hydrogen from the side chain by the $\mathrm{N}$-terminal $\alpha$-carbon radical. Subsequent formation of $\beta-\gamma$ carbon-carbon double bond leads to the elimination of the even-electron side chain and the migration of the radical center to the $\alpha$-carbon. The energy barrier for this fragmentation reaction was found to be 50 $\mathrm{kJmol}^{-1}$. (J Am Soc Mass Spectrom 2005, 16, 1523-1535) ( 2005 American Society for Mass Spectrometry

$\mathrm{P}$ rotein-based free radicals have recently attracted much attention $[1,2]$. They are important intermediates in enzymatic reactions and in oxidative damage of proteins and protein-DNA complexes. There are several well-established examples of the involvement of protein-based free radicals in enzymatic reactions [3]. The pyruvate formate lyase from the anaerobically grown Escherichia coli contains an intrinsic glycyl radical, [4] while the action of class 1 and 2 ribonucleotide reductases produces transient thiyl (RS) radicals from the side chains of cysteine residues [5]. The origins of the oxidative damage of proteins and protein-DNA complexes are predominantly related to the presence of reactive oxygen species (ROS), such as superoxide $\left(\mathrm{O}_{2}^{-}\right)$, peroxyl $(\mathrm{ROO})$, hydroxyl $(\mathrm{OH})$ radicals, and hydrogen peroxide $\left(\mathrm{H}_{2} \mathrm{O}_{2}\right)$ in the biological systems [6]. ROS are undesirable chemicals generated by side reac-

Published online July 14, 2005

Address reprint requests to Dr. T.-W. D. Chan, Department of Chemistry, The Chinese University of Hong Kong, Shatin, N.T., Hong Kong SAR, China. E-mail: twdchan@cuhk.edu.hk tions of normal metabolism, [7] ultraviolet and ionizing radiation on cells [8], and also by the action of toxic chemicals [9]. Although ROS are usually formed in extremely low concentrations, their reactions with membranes, nucleic acid, and proteins are chain processes. For peptide/protein damage, chain lengths of up to 15 have been reported $[10,11]$. The significance of this oxidative damage is implicated in numerous pathological disorders and the process of aging $[12,13]$. With the increasing usage of high-energy radiation for sterilization of food [14], the risk of generating toxic or other deleterious substances in food through radicalmediated reactions has also aroused much attention. A better understanding of the structures, relative stabilities, and propagation pathways of radicals derived from different amino acid residues is, therefore, necessary for detection and monitoring of pathological disorders in biological system, and for accessing the possible generation of undesirable substances in food, especially those of high protein content [14]. A number of excellent reviews have been published on the reaction products and reaction mechanisms involved in 
radiolysis of polypeptides in solution and in solid [1, 12]. Most of the studies involve the use of electron spin resonance (ESR) spectroscopy [15] and other product analysis methods [16] for probing the reactions between ROS and protein functions. Recently, a rather new mass spectrometry approach for sequencing mass-selected multiply-protonated polypeptide ions was introduced. This method relies on ion-electron recombination at low energy and is called electron capture dissociation (ECD) $[17,18]$. Because of its intriguing property of cleaving the protein backbone without breaking the labile sidechain modifications, such as phosphorylation [19], glycosylation [20], and methionine oxidation [21], ECD has quickly become one of the important mass spectrometry tools for de novo sequencing of polypeptides [22]. It is, however, of interest to note that product species derived from ECD of polypeptide ions show high similarity in comparison with those derived from radiolysis of polypeptides in solution and in solid. In both cases, reduction of the polypeptide species with electrons leads primarily to deamination at $\mathrm{N}$-terminal and to dissociative deamidation along the $\mathrm{N}-\mathrm{C}_{\alpha}$ linkage [12, 17]. It is, therefore, plausible that analysis of polypeptide ion decomposition in gas phase under ECD conditions might provide new insight into the radiation damage of polypeptide in condensed phase. In a recent study of cyclic peptide ions under electron capture dissociation experiments, multiple free radical induced backbone cleavages and side-chain losses were observed [23]. Many amino acid residues, including tryptophan, histidine, phenylalanine, valine, alanine, and glycine, were found to lose their characteristic side chains.

In attempts to obtain more information regarding the pathways and mechanisms of radical induced decomposition of protein, a series of custom-synthesized peptides were analyzed using electron capture dissociation mass spectrometry. From the characteristic cleavage fragments, several radical initiated decomposition pathways were proposed. The structures and energetics of these decomposition pathways were modeled using ab initio calculations. It is important to stress that gasphase reaction conditions can effectively emulate the biological situations in which the protein radicals are generated in places where the concentration of $\mathrm{O}_{2}$ is low and dimerization of protein radicals is prevented by steric factors [24]. Information obtained from this study is not available from radiolysis studies of polypeptides.

\section{Experimental}

\section{Sample Preparation}

Peptides were custom-synthesized by Peptron Inc., (Daejeon, South Korea) and were used without further purification. The samples were prepared at concentrations of $1 \times 10^{-5}$ to $1 \times 10^{-4} \mathrm{M}$ in 1:1 water:methanol (Labscan Ltd., Bangkok, Thailand) with 3\% acetic acid (Riedel-de Haen, Germany).

\section{Instrumentation}

All experiments were performed by using a 4.7 tesla FTMS system (APEX I, Bruker Instrument Inc., Boston, MA). This instrument was equipped with a standard commercially available external electrospray ion source (Analytica, Branford, CT) [25]. The ESI ion source was modified to adopt a homemade nanospray assembly [26]. Eight to ten $\mu \mathrm{L}$ of sample solution was loaded into a tapered capillary tip and was electrically grounded using a $15 \mu \mathrm{m}$ gold-plated tungsten wire [26]. WOoubly TCharged Peptide Tions There produced and were briefly accumulated in a hexapole ion guide for up to $3 \mathrm{~s}$ before transferring into the

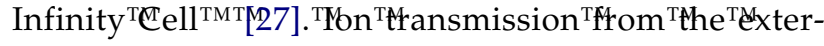
nal source into the trapped ion cell was achieved by using the standard electrostatic lens system. Sidekick $^{\mathrm{TM}}$ ion accumulation method was used to facilitate the ion trapping process. In all experiments, static trapping potential of $1.0 \mathrm{~V}$ was used. Initial calibration of the instrument was achieved by using a peptide mixture containing LGF, angiotensin II and melittin. A standard electrically heated filament source was used to produce pulses of electron beam. The filament was made of rhenium ribbon and was fixed at a distance of $108 \mathrm{~mm}$ from the rear end of the Infinity Cell. Details of the geometry of the filament source ${ }^{\mathrm{T}}$ Mave ${ }^{\mathrm{T}}$ previously ${ }^{\mathrm{T}}$ been ${ }^{\mathrm{T}}$ described ${ }^{\mathrm{T}}$ [28]. ${ }^{\mathrm{TT}} \mathrm{T}^{\mathrm{T}} \mathrm{ypical}$ experimental conditions were 3.3 A filament heating current, $4.5 \mathrm{~V}$ average filament bias voltage, and 30 to $100 \mathrm{~ms}$ electron irradiation time. No cooling gas was used in the present experiments. All ECD mass spectra were acquired in broadband mode using 128 kbyte dataset. Fifty scans were normally summed to improve the signal-to-noise ratio. The time-domain signals were zero-filled once before Fourier transformation. To achieve better mass measurement accuracy, the frequency domain spectra were internally calibrated using $\mathrm{c}^{+}$fragments.

\section{Calculations}

Standard ab initio calculations were performed by using ${ }^{\mathrm{T}}$ Gaussian ${ }^{\mathrm{T}}$ O3 ${ }^{\mathrm{T}}$ molecular ${ }^{\mathrm{T}}$ brbital ${ }^{\mathrm{T}}$ package ${ }^{\mathrm{T}}[29]$. Geometries were optimized with density functional theory calculation using spin-unrestricted Becke's hybrid ${ }^{\mathrm{T} U}$ UB3LYPTfunctional ${ }^{\mathrm{TM}}[30]^{\mathrm{TM}} \mathrm{and}^{\mathrm{T}}$ the $\mathrm{T}^{\mathrm{T}}$ 6 $-31^{\mathrm{TM}}++$ $\mathrm{G}(\mathrm{d}, \mathrm{p})$ basis set. The optimized structures were characterized by harmonic frequency analysis as local minima (all frequencies real) and first-order saddle points (single imaginary frequency). The UB3LYP frequencies were corrected by 0.9806 and were used to ${ }^{\text {THalculate }}{ }^{\text {THEero-point }}{ }^{\text {TH }}$ ibrational ${ }^{\text {TH }}$ corrections ${ }^{\text {TM }}[31]$. Single-point energies were calculated at UB3LYP and UMP2 levels using the $6-311++\mathrm{G}(3 \mathrm{df}, 2 \mathrm{p})$ basis set. Complete optimized geometries (Cartesian coordinates), uncorrected harmonic frequencies, and total energies for all species are available as supporting information. Spin contamination in calculations with 


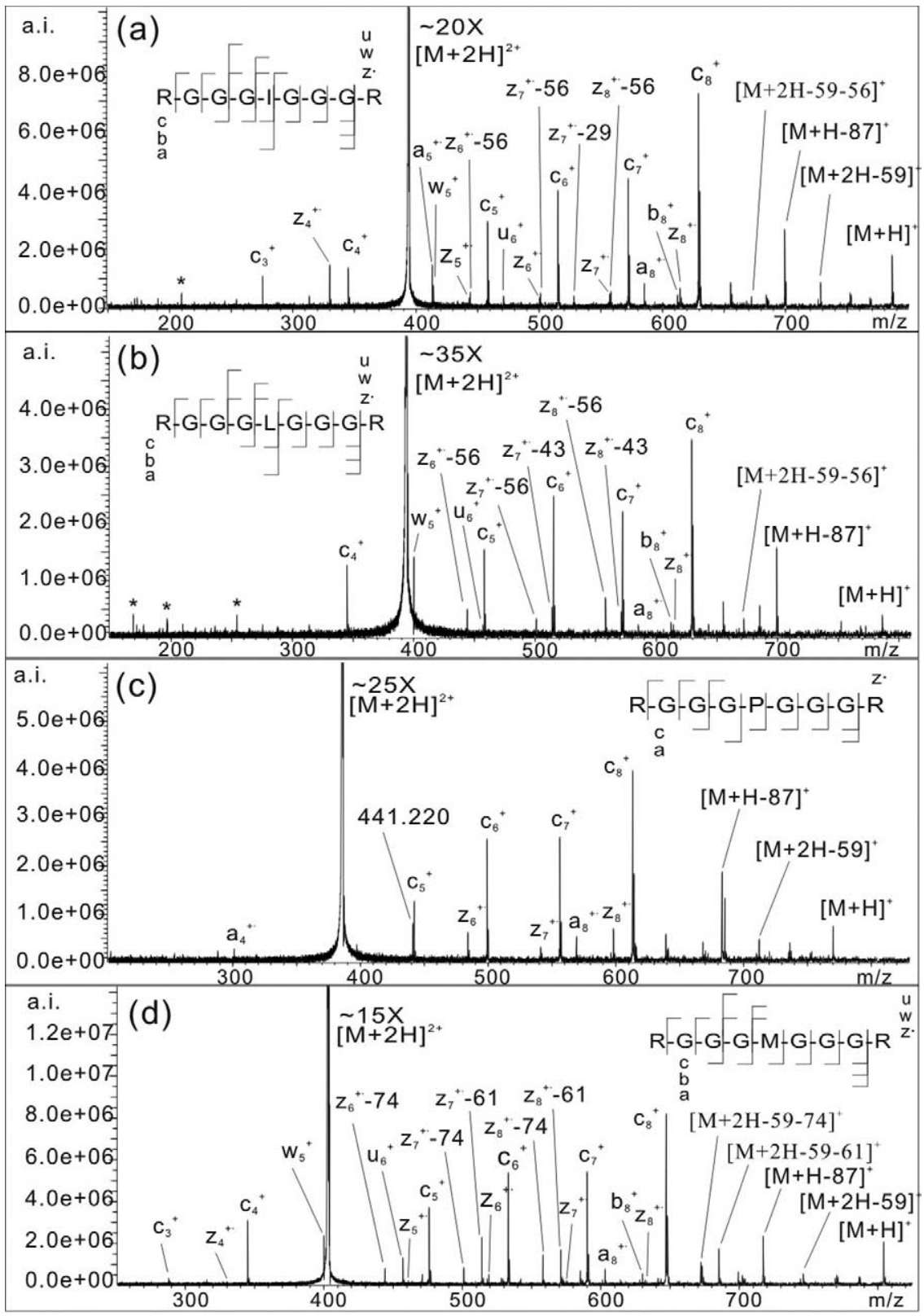

Figure 1. Typical electron capture dissociation mass spectra of RGGGXGGGR, where $X$ is (a) leucine, (b) isoleucine, (c) proline, and (d) methionone. Losses of both odd- and even-electron species from $\mathrm{z}_{\mathrm{n}}^{+}$. ions could be clearly identified.

unrestricted wave functions was negligible to moderate. The $\left\langle\mathrm{S}^{2}\right\rangle$ operator expectation values were 0.75-0.77 for UB3LYP calculations of local minima and transition states, $0.76-0.81$ for UMP2 calculations of local minima, and $0.80-1.01$ for UMP2 calculations of transition states. Spin projection (PMP2) reduced the $\left\langle\mathrm{S}^{2}\right\rangle$ values to $0.75-0.77$ and resulted in total energy corrections of $<9$ mhartree $\left(22 \mathrm{kJmol}^{-1}\right)$. The single-point energies from the UB3LYP and spinprojected MP2 calculations were averaged and used to calculate to give B3-PMP2 relative energies that were corrected for zero-point vibrational energies. Attributable, presumably, to the cancellation of errors inherent to the estimation of correlation energies in PMP2 and UB3LYP methods, the empirical average of the relative energies obtained from these methods with adequately large basis sets was shown to have good fit with experimental data or results from high-level ${ }^{\mathrm{T}} \mathrm{Cal}^{\mathrm{a}}$ culations ${ }^{\mathrm{T}}[\mathrm{B} 2]$.

\section{Results}

\section{General Features of Spectra}

The side-chain cleavage behaviors of various amino acid residues under typical ECD conditions was 
Table 1. Assignment of peaks in ECD spectrum of RGGGIGGGR. The values in the blankets are the corresponding values before internal calibration with $\mathrm{c}$ ions

\begin{tabular}{|c|c|c|c|c|}
\hline & Theoretical mass & Experimental mass & $\mathrm{S} / \mathrm{N}$ & $\begin{array}{l}\text { Error in } \\
\text { ppm }\end{array}$ \\
\hline$[\mathrm{M}+2 \mathrm{H}]^{+\bullet}$ & 787.4407 & 787.4406 (787.4383) & 3.8 & $-0.1(-3.0)$ \\
\hline$[\mathrm{M}+2 \mathrm{H}]^{+\bullet}-\bullet \mathrm{H}\left(\right.$ or $\left.[\mathrm{M}+\mathrm{H}]^{+}\right)$ & 786.4329 & $786.4369(786.4337)$ & 12.9 & $5.1(1.0)$ \\
\hline$[\mathrm{M}+\mathrm{H}]^{+}-\mathrm{NH}_{3}$ & 769.4063 & $769.4154(769.4113)$ & 2.1 & $11.7(6.4)$ \\
\hline$[\mathrm{M}+2 \mathrm{H}]^{+\bullet}-\mathrm{HN}=\mathrm{C}\left(\mathrm{NH}_{2}\right)_{2}$ & 728.3924 & $728.3946(728.3905)$ & 6.3 & $3.1(-2.6)$ \\
\hline$[\mathrm{M}+\mathrm{H}]^{+}-\mathrm{CH}_{3} \mathrm{CH}_{2} \mathrm{NHC}=\mathrm{NH}\left(\mathrm{NH}_{2}\right)$ & 699.3532 & $699.3556(699.3517)$ & 19.2 & $3.4(-2.2)$ \\
\hline $\mathrm{y}_{8}^{+}$ & 630.3318 & $630.3412(630.3353)$ & 28.4 & $15.0(5.6)$ \\
\hline $\mathrm{C}_{8}^{+}$ & 629.3478 & $629.3478(629.3439)$ & 51.8 & $0.1(-6.1)$ \\
\hline $\mathrm{z}_{8}^{+\bullet}$ & 614.3131 & $614.3184(614.3117)$ & 4.9 & $8.7(-2.2)$ \\
\hline $\mathrm{b}_{8}^{+}$ & 612.3212 & $612.3108(612.3084)$ & 3.3 & $-17.0(-21.0)$ \\
\hline$a_{8}^{+\bullet}$ & 585.3341 & $585.3384(585.3305)$ & 6.0 & $7.3(-6.1)$ \\
\hline $\mathrm{c}_{7}^{+}$ & 572.3263 & $572.3265(572.3211)$ & 31.3 & $0.3(-9.2)$ \\
\hline $\mathrm{z}_{8}^{+} \cdot-\mathrm{CH}_{3} \mathrm{C}=\mathrm{C}_{2} \mathrm{H}_{5}$ & 558.2505 & $558.2508(558.2454)$ & 4.0 & $0.7(-9.0)$ \\
\hline $\mathrm{z}_{7}^{+\bullet}$ & 557.2916 & $557.2873(557.2819)$ & 3.5 & $-7.6(-17.4)$ \\
\hline $\mathrm{z}_{7}^{+} \cdot-{ }^{\bullet} \mathrm{CH}_{2} \mathrm{CH}_{3}$ & 528.2519 & $528.2537(528.2490)$ & 3.1 & $3.3(-5.6)$ \\
\hline $\mathrm{C}_{6}^{+}$ & 515.3048 & $515.3049(515.2990)$ & 28.4 & $0.2(-11.4)$ \\
\hline $\mathrm{z}_{7}^{+\bullet}-\mathrm{CH}_{3} \mathrm{C}=\mathrm{C}_{2} \mathrm{H}_{5}$ & 501.2290 & $501.2240(501.2218)$ & 3.5 & $-10.0(-14.3)$ \\
\hline $\mathrm{z}_{6}{ }^{+\bullet}$ & 500.2701 & $500.2783(500.2657)$ & 2.5 & $16.4(-9.0)$ \\
\hline $\mathrm{z}_{6}{ }^{+\bullet}-{ }^{\bullet} \mathrm{CH}_{2} \mathrm{CH}_{3}$ & 471.2305 & $471.2319(471.2263)$ & 3.0 & $3.0(-8.8)$ \\
\hline $\mathrm{C}_{5}^{+}$ & 458.2834 & $458.2834(458.2769)$ & 21.0 & $0.1(-14.1)$ \\
\hline $\mathrm{z}_{6}{ }^{+\bullet}-\mathrm{CH}_{3} \mathrm{C}=\mathrm{C}_{2} \mathrm{H}_{5}$ & 444.2075 & 444.2067 (444.1989) & 3.8 & $-2.0(-19.4)$ \\
\hline $\mathrm{z}_{5}^{+\bullet}$ & 443.2487 & 443.2469 (443.2403) & 2.6 & $-4.0(-18.8)$ \\
\hline $\mathrm{z}_{5}{ }^{+\bullet}-{ }^{\bullet} \mathrm{CH}_{2} \mathrm{CH}_{3}$ & 414.2090 & 414.2061 (414.2004) & 5.7 & $-6.9(-20.9)$ \\
\hline $\mathrm{a}_{5}^{+}$ & 413.2614 & $413.2653(413.2592)$ & 10.4 & $9.6(-5.2)$ \\
\hline$[\mathrm{M}+2 \mathrm{H}]^{2+}$ & 393.7201 & 393.7222 (393.7157) & 1126.9 & $5.4(-11.1)$ \\
\hline $\mathrm{c}_{4}^{+}$ & 345.1993 & 345.1994 (345.1939) & 9.9 & $0.2(-15.7)$ \\
\hline $\mathrm{z}_{4}^{+\bullet}$ & 330.1646 & $330.1649(330.1602)$ & 10.5 & $0.8(-13.3)$ \\
\hline
\end{tabular}

examined by using a simplified peptide model series RGGGXGGGR, where $X$ denotes the amino acid of interest and was systematically varied from the 20 common naturally occurring amino acids. The introduction of two basic amino acid residues at the two terminals was to ensure the formation of abundant doubly charged precursor ions. The glycine residues served to minimize side-chain interactions and to

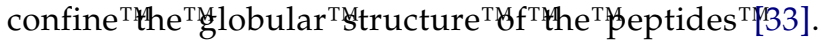

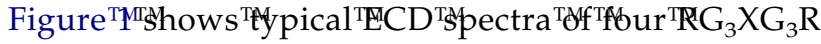
peptides, where $X$ is (a) isoleucine, (b) leucine, (c) proline, and (d) methionine. These spectra illustrate many important spectral features for the peptide series studied under electron capture dissociation conditions. Typical ECD induced fragment ions, i.e., $\mathrm{c}_{3}^{+}$to $\mathrm{c}_{8}^{+}$and $\mathrm{z}_{5}^{+\cdot}$ to $\mathrm{z}_{8}^{+\cdot}$ and peaks of corresponding $\mathrm{c}^{+}$. and $\mathrm{z}^{+}$were observed. Complete amino acid sequence of the peptides could be deduced directly from these fragments. Attributable, presumably, to the low stability of the odd electron species, $\mathrm{z}^{+}$. species were generally weaker in intensities than $\mathrm{c}^{+}$ species. Apart from the usual $\mathrm{c}^{+}$and $\mathrm{z}^{+\cdot}$ fragments, many of these peptides show cleavage products related to the side-chain losses from the arginine residues and the $X$ amino acids. Based on exact mass measurements, the molecular formulas of these fragment species were obtained and their structures were assigned. Criteria for peak assignment include a minimum signal-to-noise ratio of 2.0 and a maximum deviation bracket of \pm 15 ppm between the measured mass and the exact mass of the proposed species (Table ${ }^{\mathrm{T}} 1$ ).

\section{Neutral Loss from Reduced Precursor Ions}

The so-called $[\mathrm{M}-\mathrm{X}]$ region has been one of the focuses in literatures for interpreting the side-chain cleavages of

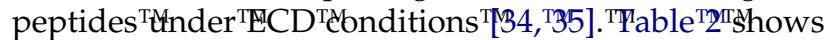
a summary of the $[\mathrm{M}-\mathrm{X}]$ region for the peptides studied. Fragments that are not related to the side-chain loss of amino acid $X$ are grouped together as "general cleavages". TDther Thore ${ }^{\mathrm{T}}$ Specific $^{\mathrm{T}}$ Pragments $^{\mathrm{T}}$ Are ${ }^{\mathrm{T}}$ tabled against the amino acid X. Among the peptides studied, the reduced precursor ion $[\mathrm{M}+2 \mathrm{H}]^{+\cdot}$ signals were generally much lower in intensities than that of $[\mathrm{M}+$ $\mathrm{H}^{+}$species. Since the singly-protonated precursor ions were carefully ejected in the isolation event, the [M + $\mathrm{H}^{+}$must be originating from the ejection of the hydrogen atom from the reduced precursor ions, and the high $[\mathrm{M}+\mathrm{H}]^{+}$to $[\mathrm{M}+2 \mathrm{H}]^{+\cdot}$ ratios might imply that direct loss of hydrogen atom from the reduced precursor ions of the present model peptide is an energetically favorable process. Consistent with other literature reports [34], TMhost ${ }^{\mathrm{T}}$ of $\mathrm{T}^{\mathrm{T}}$ the ${ }^{\mathrm{T}}$ peptide $\mathrm{T}^{\mathrm{T}}$ Sequences ${ }^{\mathrm{T}}$ Show $^{\mathrm{T}}$ Characteristic arginine side-chain losses from the reduced precursor ions, including losses of $44.037 \mathrm{Da}\left(\mathrm{CH}_{4} \mathrm{~N}_{2}\right), 59.048 \mathrm{Da}$ $\left(\mathrm{CH}_{5} \mathrm{~N}_{3}\right)$, and $101.095 \mathrm{Da}\left(\mathrm{C}_{4} \mathrm{H}_{11} \mathrm{~N}_{3}\right)$. Most of peptides studied show additional fragment peaks corresponding to the consecutive losses of 59.048 and $44.037 \mathrm{Da}$. Fourteen of the peptide sequences studied show losses 
Table 2. Loss of small fragments from the reduced precursor ions of RGGGXGGGR, where $X$ is one of the twenty amino acid residues

\begin{tabular}{|c|c|c|c|c|c|}
\hline $\begin{array}{l}\text { Cleavage } \\
\text { type }\end{array}$ & Peptide(s) & $\begin{array}{l}\text { Mass } \\
\text { loss }\end{array}$ & $\begin{array}{l}\text { Molecular } \\
\text { formula }\end{array}$ & Assignment & Exception \\
\hline \multirow[t]{10}{*}{ General } & \multirow[t]{10}{*}{ All } & 18.0106 & $\mathrm{H}_{2} \mathrm{O}$ & $\mathrm{H}_{2} \mathrm{O}$ & $\mathrm{C}, \mathrm{E}, \mathrm{F}, \mathrm{G}, \mathrm{H}, \mathrm{L}, \mathrm{P}, \mathrm{Q}, \mathrm{R}, \mathrm{S}, \mathrm{T}, \mathrm{V}, \mathrm{W}$ \\
\hline & & 34.0531 & $\mathrm{~N}_{2} \mathrm{H}_{6}$ & $2 \mathrm{NH}_{3}$ & $\mathrm{~L}, \mathrm{Q}, \mathrm{S}, \mathrm{T}, \mathrm{W}$ \\
\hline & & 44.0374 & $\mathrm{CH}_{4} \mathrm{~N}_{2}$ & $\mathrm{HC}\left(\mathrm{NH}_{2}\right)=\mathrm{NH}[\mathrm{Arg}]$ & $\begin{array}{l}A, F, G, I, K, L, M, N, P, Q, S, T, V, \\
\quad W, Y\end{array}$ \\
\hline & & 59.0483 & $\mathrm{CH}_{5} \mathrm{~N}_{3}$ & $\mathrm{HN}=\mathrm{C}\left(\mathrm{NH}_{2}\right)_{2}[\mathrm{Arg}]$ & $\mathrm{C}, \mathrm{L}$ \\
\hline & & 103.0858 & $\mathrm{C}_{2} \mathrm{H}_{9} \mathrm{~N}_{5}$ & $\begin{array}{l}\mathrm{HN}=\mathrm{C}\left(\mathrm{NH}_{2}\right)_{2}[\mathrm{Arg}] \text { and } \mathrm{HC}\left(\mathrm{NH}_{2}\right)=\mathrm{NH} \\
\quad[\mathrm{Arg}]\end{array}$ & $\mathrm{D}, \mathrm{H}, \mathrm{L}, \mathrm{W}$ \\
\hline & & 101.0953 & $\mathrm{C}_{4} \mathrm{H}_{11} \mathrm{~N}_{3}$ & $\mathrm{CH}_{3} \mathrm{CH}_{2} \mathrm{CH}_{2} \mathrm{NHC}\left(\mathrm{NH}_{2}\right)=\mathrm{NH}[\mathrm{Arg}]$ & $E, F, L, M, P, Q, S, V^{\S}$ \\
\hline & & 18.0344 & $\bullet \mathrm{NH}_{4}$ & $\bullet \mathrm{H} \& \mathrm{NH}_{3}$ & $\mathrm{~A}, \mathrm{D}, \mathrm{E}, \mathrm{G}, \mathrm{I}, \mathrm{K}, \mathrm{L}, \mathrm{MN}, \mathrm{Q}, \mathrm{S}, \mathrm{Y}$ \\
\hline & & 19.0184 & $\bullet \mathrm{H}_{3} \mathrm{O}$ & $\bullet \mathrm{H} \& \mathrm{H}_{2} \mathrm{O}$ & $\mathrm{E}, \mathrm{F}, \mathrm{G}, \mathrm{H}, \mathrm{K}, \mathrm{L}, \mathrm{P}, \mathrm{Q}, \mathrm{R}, \mathrm{S}, \mathrm{W}$ \\
\hline & & 35.0609 & $\cdot \mathrm{N}_{2} \mathrm{H}_{7}$ & $\bullet \mathrm{H} \& 2 \mathrm{NH}_{3}$ & $\mathrm{D}, \mathrm{E}, \mathrm{Q}, \mathrm{R}, \mathrm{S}, \mathrm{T}, \mathrm{W}$ \\
\hline & & 88.0875 & ${ }^{\circ} \mathrm{C}_{3} \mathrm{H}_{10} \mathrm{~N}_{3}$ & $\bullet \mathrm{H} \& \mathrm{CH}_{3} \mathrm{CH}_{2} \mathrm{NHC}\left(\mathrm{NH}_{2}\right)=\mathrm{NH}[\mathrm{Arg}]$ & $\mathrm{K}$ \\
\hline \multirow{14}{*}{$\begin{array}{l}\text { Sequence } \\
\text { specific }^{\mathrm{a}}\end{array}$} & Valine $(\mathrm{V})^{\mathrm{b}}$ & 101.0953 & $\mathrm{C}_{4} \mathrm{H}_{11} \mathrm{~N}_{3}$ & $\mathrm{HNC}\left(\mathrm{NH}_{2}\right)_{2}[\mathrm{Arg}] \& \mathrm{C}_{3} \mathrm{H}_{6}[\mathrm{Val}]$ & \\
\hline & Leucine (L) & 115.1109 & $\mathrm{C}_{5} \mathrm{H}_{13} \mathrm{~N}_{3}$ & $\mathrm{HNC}\left(\mathrm{NH}_{2}\right)_{2}[\mathrm{Arg}] \& \mathrm{C}_{4} \mathrm{H}_{8}[\mathrm{Leu}]$ & \\
\hline & Isoleucine (I) & 115.1109 & $\mathrm{C}_{5} \mathrm{H}_{13} \mathrm{~N}_{3}$ & $\mathrm{HNC}\left(\mathrm{NH}_{2}\right)_{2}[\mathrm{Arg}] \& \mathrm{C}_{4} \mathrm{H}_{8}[\mathrm{Ile}]$ & \\
\hline & Aspartic Acid (D) & 103.0382 & $\mathrm{C}_{2} \mathrm{H}_{5} \mathrm{~N}_{3} \mathrm{O}_{2}$ & $\mathrm{HNC}\left(\mathrm{NH}_{2}\right)_{2}[\mathrm{Arg}] \& \mathrm{CO}_{2}[\mathrm{Asp}]$ & \\
\hline & $\begin{array}{l}\text { Glutamic Acid } \\
\text { (E) }\end{array}$ & 131.0695 & $\mathrm{C}_{4} \mathrm{H}_{9} \mathrm{~N}_{3} \mathrm{O}_{2}$ & $\mathrm{HNC}\left(\mathrm{NH}_{2}\right)_{2}[\mathrm{Arg}] \& \mathrm{C}_{3} \mathrm{H}_{4} \mathrm{O}_{2}[\mathrm{Glu}]$ & \\
\hline & Lysine (K) & 130.1218 & $\mathrm{C}_{5} \mathrm{H}_{14} \mathrm{~N}_{4}$ & $\mathrm{HNC}\left(\mathrm{NH}_{2}\right)_{2}[\mathrm{Arg}] \& \mathrm{C}_{4} \mathrm{H}_{9} \mathrm{~N}[\mathrm{Lys}]$ & \\
\hline & Asparagine $(\mathrm{N})$ & 103.0620 & ${ }^{-} \mathrm{C}_{2} \mathrm{H}_{7} \mathrm{~N}_{4} \mathrm{O}$ & $\mathrm{HNC}\left(\mathrm{NH}_{2}\right)_{2}\left[\right.$ Arg] $\&{ }^{\bullet} \mathrm{CONH}_{2}[$ Asn] & \\
\hline & Glutamine (Q) & 117.0776 & ${ }^{-} \mathrm{C}_{3} \mathrm{H}_{9} \mathrm{~N}_{4} \mathrm{O}$ & $\mathrm{HNC}\left(\mathrm{NH}_{2}\right)_{2}[\mathrm{Arg}] \&{ }^{\circ} \mathrm{C}_{2} \mathrm{H}_{4} \mathrm{NO}[\mathrm{GIn}]$ & \\
\hline & \multirow[t]{2}{*}{ Methionine (M) } & 120.0601 & ${ }^{-} \mathrm{C}_{2} \mathrm{H}_{10} \mathrm{~N}_{3} \mathrm{~S}$ & $\mathrm{HNC}\left(\mathrm{NH}_{2}\right)_{2}[\mathrm{Arg}] \&{ }^{\bullet} \mathrm{CH}_{2} \mathrm{SCH}_{3}[$ Met $]$ & \\
\hline & & 133.0674 & $\mathrm{C}_{4} \mathrm{H}_{11} \mathrm{~N}_{3} \mathrm{~S}$ & $\mathrm{HNC}\left(\mathrm{NH}_{2}\right)_{2}[\mathrm{Arg}] \& \mathrm{C}_{3} \mathrm{H}_{6} \mathrm{~S}[\mathrm{Met}]$ & \\
\hline & Histidine $(\mathrm{H})$ & 82.0531 & $\mathrm{C}_{4} \mathrm{H}_{6} \mathrm{~N}_{2}$ & $\mathrm{C}_{4} \mathrm{H}_{6} \mathrm{~N}_{2}[\mathrm{His}]$ & \\
\hline & Tryptophan (W) & 131.074 & $\mathrm{C}_{8} \mathrm{H}_{8} \mathrm{~N}$ & $\mathrm{C}_{8} \mathrm{H}_{8} \mathrm{~N}[\mathrm{Trp}]$ & \\
\hline & & 175.0989 & ${ }^{-} \mathrm{C}_{9} \mathrm{H}_{11} \mathrm{~N}_{4}$ & $\mathrm{HNC}\left(\mathrm{NH}_{2}\right)_{2}[\mathrm{Arg}] \&{ }^{\bullet} \mathrm{C}_{8} \mathrm{H}_{6} \mathrm{~N}[\mathrm{Trp}]$ & \\
\hline & Tyrosine (Y) & 165.0902 & $\mathrm{C}_{3} \mathrm{H}_{11} \mathrm{~N}_{3} \mathrm{O}$ & $\mathrm{HNC}\left(\mathrm{NH}_{2}\right)_{2}[\mathrm{Arg}] \& \mathrm{C}_{7} \mathrm{H}_{6} \mathrm{O}[\mathrm{Tyr}]$ & \\
\hline
\end{tabular}

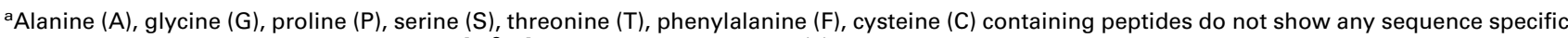
cleavage related to the $\mathrm{X}$-amino acid at the $\left[\mathrm{M}^{\bullet}-\mathrm{X}\right]$ region. Specific cleavage(s) derived from peptide with an arginine residue at $\mathrm{X}$-position could not be distinguished from that derived from the arginine residues at $\mathrm{C}$ - and $\mathrm{N}$-terminals.

bElimination of $\mathrm{C}_{4} \mathrm{H}_{11} \mathrm{~N}_{3}$ [Arg] fragment has the same mass loss as the cumulative elimination of $\mathrm{HNC}\left(\mathrm{NH}_{2}\right)_{2}[\mathrm{Arg}]$ \& $\mathrm{C}_{3} \mathrm{H}_{6}[\mathrm{Val}]$ moieties.

of small neutral fragments that are related to the side chain of the amino acid residue at the $\mathrm{X}$ position. Instead of direct side-chain cleavage from the reduced precursor ions, almost all of these cleavages occur after the arginine side-chain cleavage, i.e., from the $[\mathrm{M}+2 \mathrm{H}$ $-59.048]^{+\cdot}$ species. Exceptions to this are found in the histidine- and tryptophan-related peptides in which peaks corresponding to the loss of the their corresponding side chains (i.e., -82.053 and $-131.074 \mathrm{Da}$ ) for histidine- and tryptophan-containing peptides, respectively, from the $[\mathrm{M}+2 \mathrm{H}]^{+\cdot}$ were found. Such differences in fragmentation patterns provide insights into the dissociation process. Side-chain dissociations of histidine and arginine have similar preferences and are preferred over other amino acid side chains. A plausible explanation is related to the protonation site which is also the electron-ion recombination site. It is known that the gas-phase basicities of arginine and histidine are comparable and are much higher than other amino acid residues. They should be the preferred sites of protonation upon the formation of the doubly-protonated molecular ions. Because ECD is a very fast nonergodic

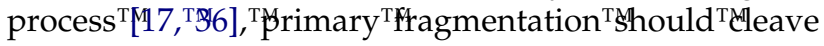
linkages in the vicinity of the recombination site, i.e., the histidine and arginine side chains. Other side-chain losses might arise from subsequent unimolecular dissociation of the metastable products, i.e., the [M $\left.\mathrm{HNC}\left(\mathrm{NH}_{2}\right)_{2}\right]^{+.}$. Some of the peptide sequences lost odd-electron neutral fragments (e.g., asparagines, glutamine, and tryptophan), whereas some of them lost even-electron neutral fragments (e.g., isoleucine, leucine, valine, aspartic acid, glutamic acid, lysine, and tyrosine). The methionine-containing peptide was observed to lose both even- and odd-electron neutral fragments. Many of these losses were also found in the fragmentation of the labile $\mathrm{z}^{+\cdot}$ species (see below). The fragmentation mechanisms will be discussed in the following sections.

\section{Neutral Loss from $z_{n}^{+}$.}

Apart from the reduced precursor ions, the labile $\mathrm{z}^{+}$ fragments were found to undergo extensive secondary

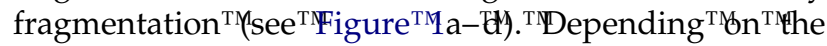
identity of the amino acid at the $X$ position, further losses of odd- and/or even-electron neutral species

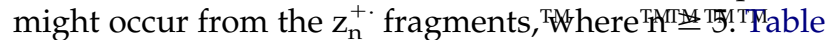

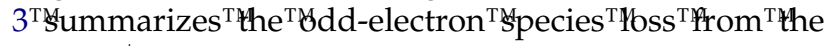
labile $\mathrm{z}^{+\cdot}$ fragments. Thirteen out of the twenty model peptides were found to show secondary side-chain 
cleavage from the $\mathrm{z}^{+\cdot}$ species involving losses of oddelectron fragments. Valine-, leucine- [37], isoleucine[37], glutamic acid-, asparagines-, glutamine-, cysteineand methionine-containing peptides were found to lose odd-electron side chains, i.e., $15.0240 \mathrm{Da}\left(\mathrm{CH}_{3}\right), 43.0548$ $\left(\mathrm{C}_{3} \mathrm{H}_{7}\right), 29.0397\left(\mathrm{C}_{2} \mathrm{H}_{5}\right), 59.0133\left(\mathrm{C}_{2} \mathrm{H}_{3} \mathrm{O}_{2}\right), 44.0136$ $\left(\mathrm{CONH}_{2}\right), 58.0293\left(\mathrm{C}_{2} \mathrm{H}_{4} \mathrm{NO}\right), 32.9804(\mathrm{SH})$, and $61.0117\left({ }^{\circ} \mathrm{C}_{2} \mathrm{H}_{5} \mathrm{~S}\right)$, respectively, from $\mathrm{z}_{\mathrm{n}}^{+}$s species, where $n$ $\geq 5$. For aspartic acid-containing peptide, loss of $44.9977 \mathrm{Da}\left(\cdot \mathrm{CO}_{2} \mathrm{H}\right)$ was observed from $\mathrm{z}_{5}^{+}$only, whereas loss of $58.0662 \mathrm{Da}\left(\cdot \mathrm{C}_{3} \mathrm{H}_{8} \mathrm{~N}\right)$ side chain was observed from all $z_{\mathrm{n}}^{+\cdot}$ (where $n \geq 6$ ) of lysine-containing peptide. It is worthy to note that peptide sequences whose $\mathrm{X}$ amino acid has an aromatic side chain (such as phenylalanine, histidine and tyrosine) on their $\beta$-carbons did not show any loss of odd-electron species from the $\mathrm{z}^{+\cdot}$ fragments. Similar observations were found in the loss of the odd-electron species from the $z^{+\cdot}$ fragments derived under high-energy CAD of radical cation of ${ }^{\mathrm{T}} \mathrm{Peptides}{ }^{\mathrm{T}}[\mathrm{B} 8]$. TThe $^{\mathrm{T}} \mathrm{Z}_{\mathrm{n}}^{+\cdot}$ fragments derived from proline-, serine-, and threonine-containing peptides were found to behave rather differently and generated prominent secondary fragment ions at 414.220, 416.189, and 430.204 , respectively.

Besides the loss of radical species, eleven amino acid residues were shown to lose even-electron side chains from the labile $\mathrm{z}^{+\cdot}$ fragments under ECD conditions.

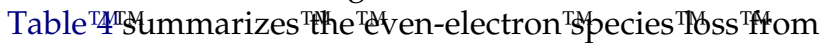
the labile $z_{n}^{+\cdot}$ fragments, where $n \geq 6$. Even-electron

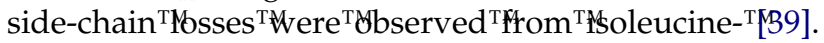
cysteine-, glutamate-, glutamic acid-, lysine-, leucine-, methionine-, tryptophan-, and tyrosine-containing peptides with losses of $56.063 \mathrm{Da}\left(\mathrm{C}_{4} \mathrm{H}_{8}\right), 45.988 \mathrm{Da}\left(\mathrm{CH}_{2} \mathrm{~S}\right)$, $71.037 \mathrm{Da}\left(\mathrm{C}_{3} \mathrm{H}_{5} \mathrm{NO}\right), 72.021 \mathrm{Da}\left(\mathrm{C}_{3} \mathrm{H}_{4} \mathrm{O}_{2}\right), 71.073 \mathrm{Da}$ $\left(\mathrm{C}_{4} \mathrm{H}_{9} \mathrm{~N}\right), 56.063 \mathrm{Da}\left(\mathrm{C}_{4} \mathrm{H}_{8}\right), 74.019 \mathrm{Da}\left(\mathrm{C}_{3} \mathrm{H}_{6} \mathrm{~S}\right), 129.0579$ Da $\left(\mathrm{C}_{9} \mathrm{H}_{7} \mathrm{~N}\right)$, and $106.042 \mathrm{Da}\left(\mathrm{C}_{7} \mathrm{H}_{6} \mathrm{O}\right)$, respectively. In all cases, such side-chain losses were not found in $\mathrm{z}_{5}^{+}$. fragments.

Based on the present findings, information regarding pathways of radical initiated protein degradation could be extracted. Although the predominant reaction pathway for protein radical in condensed phase is dimerization, unimolecular decomposition of protein radicals in gas phase can still provide new perspectives into the fate of protein radicals. Protein radicals might be generated in places where dimerization reaction is prohibited ${ }^{\mathrm{T}}[\mathrm{p} 4]$.

\section{Discussion}

The primary cleavage of electron reduced peptide species has been extensively studied. The prevailing mechanisms involve either single step proton-coupled electron transfer from the hypervalent amino group to the

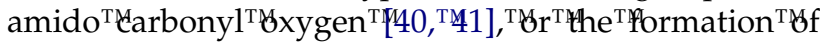
super-basic amido radical that abstracts a proton from a

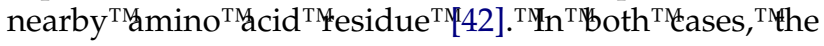
formation of labile aminoketyl radicals would induce characteristics $\mathrm{N}-\mathrm{C}_{\alpha}$ backbone cleavage. Structures and energetics of the reactions have been characterized

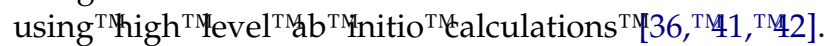
However, relatively little is known concerning the fate of the carbon-based radicals after the $\mathrm{N}-\mathrm{C}_{\alpha}$ cleavage

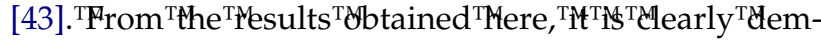
onstrated that the carbon-based radical center can initiate a series of reactions leading to the apparent loss of the side chains from different side-chain containing amino acid residues. Empirically, the radical center can trigger the cleavage of the linkage between the $\beta$ - and $\gamma$-carbons of the amino acid side chain with the retention of the radical center at the leaving fragment containing the $\gamma$-carbon. In addition, the radical center can also cause the cleavage of the linkage between the $\alpha$ and $\beta$-carbons with a concomitant migration of a hydrogen atom from the side chain to the peptide backbone. To obtain additional information regarding the radical structures and energetics of the secondary fragmentation reactions, we have performed some ab initio calculations using two leucine-based models. Because of the size limit of the leucine models, only reactions between the radical center and nearby atoms are considered. Reactions between the radical center and more distant atoms are possible; they are not discussed in this paper.

\section{Structures and Energetics of Radical-Induced Peptide Degradation}

Deamino N-methyl-leucinamide radical, Leu- $\mathrm{NH}\left(\mathrm{CH}_{3}\right)$, in model 1 and deamino-glycyl-N-methyl-leucinamide radical, Gly-Leu- $\mathrm{NH}\left(\mathrm{CH}_{3}\right)$, in model 2 were used to study the structures and energetics of the proposed dissociation pathways of $\mathrm{N}$-terminal $\alpha$-carbon radical containing peptides. Model 1 deals with the situation in which the leucine is the N-terminal amino acid in the radical species; whereas model 2 deals with the situation in which the leucine is located at a position other than the N-terminal. The calculation results were summarized ${ }^{\mathrm{T}} \mathrm{M}_{\mathrm{H}}^{\mathrm{T}} \mathrm{T} \mathrm{Table} \mathrm{TS}^{\mathrm{TS}}$.

The $\alpha$-carbon of deamino-N-methyl-leucinamide radical (1a) adopts a sp2 hybridization with the unpaired electron delocalizing along the $\mathrm{C}-\mathrm{C}(\mathrm{O})-\mathrm{N}$ $\pi$-network. The dihedral angel for HCCO is $<3^{\circ}$. Loss of $\mathrm{CH}\left(\mathrm{CH}_{3}\right)_{2}$ from deamino-N-methyl-leucinamide radical is endothermic and requires moderate activation energy, $\Delta \mathrm{H}_{\mathrm{rxn}}=+96 \mathrm{kJmol}^{-1}$ and $\mathrm{E}_{\mathrm{TS}}=111$ $\mathrm{kJmol}^{-1}$ for $\mathbf{1 a} \rightarrow \mathrm{TS} 1 \mathrm{ab} \rightarrow \mathbf{1 b}+\mathrm{CH}\left(\mathrm{CH}_{3}\right)_{2}$ (Scheme 1). Alternatively, loss of $\mathrm{CH}_{2}=\mathrm{C}\left(\mathrm{CH}_{3}\right)_{2}$ moiety proceeds via a two-step mechanism. A 1,3-hydrogen shift via a four-membered ring transition (TS1ac) state requires a much higher activation energy, $\mathrm{E}_{\mathrm{TS}}=$ $152 \mathrm{kJmol}^{-1}$. This process is slightly endothermic $(\Delta \mathrm{H}$ $=+13 \mathrm{kJmol}^{-1}$ ) because of the migration of the conjugated radical center to the $\gamma$-carbon, where the two electron donating methyl groups further destabilize the intermediate Structure 1c. The second step of the reaction involves the elimination of $\mathrm{CH}_{2}=$ 
Table 3. Losses of odd-electron species from $z_{n}{ }^{+}$. fragments of RGGGXGGGR, where $X$ is one of the twenty amino acid residues

\begin{tabular}{|c|c|c|c|c|c|c|}
\hline Amino acid & Mass loss from $z_{n}{ }^{+\bullet}$ & Molecular formula & Assignment & $\begin{array}{l}\text { Mass } \\
\text { loss } \\
\text { from } \\
\mathrm{z}_{5}{ }^{+\bullet}\end{array}$ & $\begin{array}{l}\text { Molecular } \\
\text { formula }\end{array}$ & Assignment \\
\hline Glycine (G) & - & - & - & - & - & - \\
\hline Alanine (A) & - & - & - & - & - & - \\
\hline Valine (V) & 15.0240 & $\cdot{ }^{\circ} \mathrm{CH}_{3}$ & $\cdot{ }^{\circ} \mathrm{CH}_{3}$ & 15.0240 & ${ }^{\bullet} \mathrm{CH}_{3}$ & ${ }^{\bullet} \mathrm{CH}_{3}$ \\
\hline Leucine (L) & 43.0548 & ${ }^{\bullet} \mathrm{C}_{3} \mathrm{H}_{7}$ & ${ }^{-} \mathrm{CH}\left(\mathrm{CH}_{3}\right)_{2}$ & 43.0548 & ${ }^{\bullet} \mathrm{C}_{3} \mathrm{H}_{7}$ & - $\left.\mathrm{CH}\left(\mathrm{CH}_{3}\right)_{2}\right)$ \\
\hline Isoleucine (I) & 29.0397 & ${ }^{-} \mathrm{C}_{2} \mathrm{H}_{5}$ & ${ }^{-} \mathrm{CH}_{2} \mathrm{CH}_{3}$ & 29.0397 & $\cdot{ }^{-} \mathrm{C}_{2} \mathrm{H}_{5}$ & $\cdot{ }^{\circ} \mathrm{CH}_{2} \mathrm{CH}_{3}$ \\
\hline Proline $(P)^{a}$ & $43.0198+57.0215 \mathrm{~m}$ & ${ }^{-} \mathrm{C}_{2} \mathrm{H}_{3} \mathrm{O}\left(\mathrm{C}_{2} \mathrm{H}_{3} \mathrm{NO}\right)_{\mathrm{m}}$ & $\mathrm{CH}_{3}\left(\mathrm{HNCH}_{2} \mathrm{C}(\mathrm{O})\right)_{\mathrm{m}}{ }^{\circ} \mathrm{C}(\mathrm{O})$ & - & - & - \\
\hline Lysine (K) & 58.0662 & ${ }^{-} \mathrm{C}_{3} \mathrm{H}_{\mathrm{g}} \mathrm{N}$ & ${ }^{-} \mathrm{CH}_{2} \mathrm{CH}_{2} \mathrm{CH}_{2} \mathrm{NH}_{2}$ & - & - & - \\
\hline Arginine (R) & - & - & 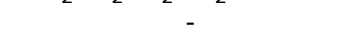 & - & - & - \\
\hline Serine $(S)^{b}$ & $58.0298+57.0215 \mathrm{~m}$ & ${ }^{\bullet} \mathrm{C}_{2} \mathrm{H}_{4} \mathrm{NO}\left(\mathrm{C}_{2} \mathrm{H}_{3} \mathrm{NO}\right)_{\mathrm{m}}$ & $\begin{array}{l}\mathrm{CH}_{3} \mathrm{C}(\mathrm{O})\left(\mathrm{HNCH}_{2} \mathrm{C}(\mathrm{O})\right)_{\mathrm{m}} \\
\cdot \mathrm{NH}\end{array}$ & - & - & - \\
\hline Threonine $(T)^{b}$ & $58.0298+57.0215 \mathrm{~m}$ & ${ }^{-} \mathrm{C}_{2} \mathrm{H}_{4} \mathrm{NO}\left(\mathrm{C}_{2} \mathrm{H}_{3} \mathrm{NO}\right)_{\mathrm{m}}$ & $\begin{array}{l}\mathrm{CH}_{3} \mathrm{C}(\mathrm{O}) \\
\left(\mathrm{HNCH}_{2} \mathrm{C}(\mathrm{O})\right)_{\mathrm{m}} \cdot \mathrm{NH}\end{array}$ & - & - & - \\
\hline Aspartic Acid (D) & - & - & - & 44.9977 & ${ }^{\bullet} \mathrm{CHO}_{2}$ & ${ }^{\bullet} \mathrm{COOH}$ \\
\hline Glutamic Acid (E) & 59.0133 & ${ }^{-} \mathrm{C}_{2} \mathrm{H}_{3} \mathrm{O}_{2}$ & ${ }^{\bullet} \mathrm{CH}_{2} \mathrm{COOH}$ & 59.0133 & ${ }^{\bullet} \mathrm{C}_{2} \mathrm{H}_{3} \mathrm{O}_{2}$ & - $\mathrm{CH}_{2} \mathrm{COOH}$ \\
\hline Asparagine $(\mathrm{N})$ & 44.0136 & ${ }^{\circ} \mathrm{CONH}_{2}$ & ${ }^{\bullet} \mathrm{C}(\mathrm{O}) \mathrm{NH}_{2}$ & 44.0136 & ${ }^{\bullet} \mathrm{CONH}_{2}$ & ${ }^{\bullet} \mathrm{C}(\mathrm{O}) \mathrm{NH}_{2}$ \\
\hline Glutamine (Q) & 58.0293 & ${ }^{\bullet} \mathrm{C}_{2} \mathrm{H}_{4} \mathrm{NO}$ & ${ }^{-} \mathrm{CH}_{2} \mathrm{C}(\mathrm{O}) \mathrm{NH}_{2}$ & 58.0293 & ${ }^{\bullet} \mathrm{C}_{2} \mathrm{H}_{4} \mathrm{NO}$ & ${ }^{\bullet} \mathrm{CH}_{2} \mathrm{C}(\mathrm{O}) \mathrm{NH}_{2}$ \\
\hline Cysteine (C) & 32.9804 & • $\mathrm{SH}$ & $\bullet \mathrm{SH}$ & 32.9804 & $\bullet \mathrm{SH}$ & • $\mathrm{SH}$ \\
\hline Methionine (M) & 61.0117 & ${ }^{-} \mathrm{C}_{2} \mathrm{H}_{5} \mathrm{~S}$ & ${ }^{-} \mathrm{CH}_{2} \mathrm{CH}_{3}$ & 61.0117 & ${ }^{-} \mathrm{C}_{2} \mathrm{H}_{5} \mathrm{~S}$ & ${ }^{\circ} \mathrm{CH}_{2} \mathrm{SCH}_{3}$ \\
\hline Phenylalanine (F) & - & - & - & - & - & - \\
\hline Histidine (H) & - & - & - & - & - & - \\
\hline Tryptophan (W) & 116.0505 & ${ }^{\bullet} \mathrm{C}_{8} \mathrm{H}_{6} \mathrm{~N}$ & & 116.0505 & ${ }^{\bullet} \mathrm{C}_{8} \mathrm{H}_{6} \mathrm{~N}$ & \\
\hline Tyrosine $(Y)$ & - & - & - & - & - & - \\
\hline
\end{tabular}

aThis fragmentation pathway involves the cleavage of $\mathrm{C}(\mathrm{O})-\mathrm{N}$ linkage at the $\mathrm{N}$-terminal side of proline residue and will generate the same secondary fragment ion at $\mathrm{m} / \mathrm{z} 441.220$ from $\mathrm{z}_{\mathrm{n}}{ }^{+\bullet}$ species, where $\mathrm{n} \geq 6$.

${ }^{b}$ This fragmentation pathway involves the cleavage of $\mathrm{N}-\mathrm{C}_{\mathrm{a}}$ linkage at the $\mathrm{N}$-terminal side of serine and threonine residues and will generate the same secondary fragment ion at $m / z 416.189$ and 430.204 , respectively, from their $z_{n}{ }^{+}$species, where $n \geq 6$.

Table 4. Losses of even-electron species from $\mathrm{z}_{\mathrm{n}}{ }^{+}$fragments of RGGGXGGGR, where $\mathrm{X}$ is one of the twenty amino acid residues

\begin{tabular}{|c|c|c|c|c|}
\hline Amino acid & $\begin{array}{l}\text { Possess } \gamma \text {-hydrogen } \\
\text { in side chain? }\end{array}$ & Mass loss from $z^{+\bullet}$ & Molecular formula & Assignment \\
\hline Glycine (G) & $\mathrm{N}$ & - & - & - \\
\hline Alanine $(A)$ & $\mathrm{N}$ & - & - & - \\
\hline Valine $(\mathrm{V})^{\mathrm{a}}$ & $\mathrm{Y}$ & $(42.0470)^{\#}$ & $\left(\mathrm{C}_{3} \mathrm{H}_{6}\right)$ & $\left(\mathrm{CH}_{2}=\mathrm{CHCH}_{3}\right)$ \\
\hline Leucine (L) & $\mathrm{Y}$ & 56.0626 & $\mathrm{C}_{4} \mathrm{H}_{8}$ & $\mathrm{CH}_{2}=\mathrm{C}\left(\mathrm{CH}_{3}\right)_{2}$ \\
\hline Isoleucine (I) & $\mathrm{Y}$ & 56.0626 & $\mathrm{C}_{4} \mathrm{H}_{8}$ & $\mathrm{CH}_{3} \mathrm{CH}=\mathrm{CHCH}_{3}$ \\
\hline Proline $(\mathrm{P})$ & $\mathrm{Y}$ & - & - & - \\
\hline Lysine (K) & $\mathrm{Y}$ & 71.0735 & $\mathrm{C}_{4} \mathrm{H}_{9} \mathrm{~N}$ & $\mathrm{H}_{2} \mathrm{C}=\mathrm{CHCH}_{2} \mathrm{CH}_{2} \mathrm{NH}_{2}$ \\
\hline Arginine $(R)$ & $\mathrm{Y}$ & 99.0796 & $\mathrm{C}_{4} \mathrm{H}_{9} \mathrm{~N}_{3}$ & $\mathrm{H}_{2} \mathrm{C}=\mathrm{CHCH}_{2}-\mathrm{NHC}(\mathrm{NH}) \mathrm{NH}_{2}$ \\
\hline Serine (S) & $\mathrm{N}$ & - & - & - \\
\hline Threonine $(\mathrm{T})$ & $\mathrm{Y}$ & - & - & - \\
\hline Aspartic Acid (D) & $\mathrm{N}$ & 43.9898 & $\mathrm{CO}_{2}$ & $\mathrm{O}=\mathrm{C}=\mathrm{O}$ \\
\hline Glutamic Acid (E) & $\mathrm{Y}$ & 72.0211 & $\mathrm{C}_{3} \mathrm{H}_{4} \mathrm{O}_{2}$ & $\mathrm{CH}_{2}=\mathrm{CHCOOH}$ \\
\hline Asparagine (N) & $\mathrm{N}$ & - & - & - \\
\hline Glutamine (Q) & $\mathrm{Y}$ & 71.0371 & $\mathrm{C}_{3} \mathrm{H}_{5} \mathrm{NO}$ & $\mathrm{CH}_{2}=\mathrm{CHC}(\mathrm{O}) \mathrm{NH}_{2}$ \\
\hline Cysteine (C) & $Y$ & 45.9877 & $\mathrm{CH}_{2} \mathrm{~S}$ & $\mathrm{~S}=\mathrm{CH}_{3}$ \\
\hline Methionine (M) & $\mathrm{Y}$ & 74.0190 & $\mathrm{C}_{3} \mathrm{H}_{6} \mathrm{~S}$ & $\mathrm{CH}_{2}=\mathrm{CHSCH}_{3}$ \\
\hline Phenylalanine (F) & $\mathrm{N}$ & - & - & - \\
\hline Histidine $(\mathrm{H})$ & $\mathrm{N}$ & - & - & - \\
\hline Tryptophan (W) & $\mathrm{N}$ & 129.0579 & $\mathrm{C}_{9} \mathrm{H}_{7} \mathrm{~N}$ & \\
\hline Tyrosine $(\mathrm{Y})$ & $N$ & 106.0419 & $\mathrm{C}_{7} \mathrm{H}_{6} \mathrm{O}$ & $\mathrm{CH}_{2}\left(\mathrm{C}_{6} \mathrm{H}_{4} \mathrm{O}\right)$ \\
\hline
\end{tabular}

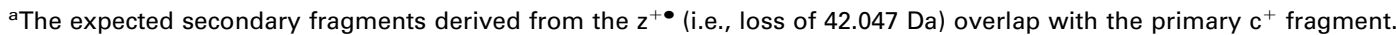


Table 5. Energies of Model 1 and 2

\begin{tabular}{|c|c|c|c|c|}
\hline \multirow[b]{3}{*}{ Species/reaction } & \multicolumn{4}{|c|}{ Relative energy ${ }^{a}$} \\
\hline & \multicolumn{2}{|c|}{$6-31++G(d, p)$} & \multicolumn{2}{|c|}{$6-311++G(3 d f, 2 p)$} \\
\hline & B3LYP & B3LYP & PMP2 & B3-MP2 \\
\hline $1 \mathrm{a} \rightarrow 1 \mathrm{~b}+{ }^{\bullet} \mathrm{CH}\left(\mathrm{CH}_{3}\right)_{2}$ & 83 & 75 & 118 & 96 \\
\hline $1 \mathrm{a} \rightarrow \mathrm{TS} 1 \mathrm{ab}$ & 103 & 97 & 124 & 111 \\
\hline $1 \mathrm{a} \rightarrow 1 \mathrm{~d}+\mathrm{CH}_{2}=\mathrm{C}\left(\mathrm{CH}_{3}\right)_{2}$ & 72 & 64 & 100 & 82 \\
\hline $1 \mathrm{a} \rightarrow 1 \mathrm{c}$ & 11 & 10 & 15 & 13 \\
\hline $1 \mathrm{a} \rightarrow \mathrm{TS} 1 \mathrm{ac}$ & 153 & 153 & 151 & 152 \\
\hline $1 \mathrm{c} \rightarrow 1 \mathrm{~d}+\mathrm{CH}_{2}=\mathrm{C}\left(\mathrm{CH}_{3}\right)_{2}$ & 61 & 54 & 84 & 69 \\
\hline $1 \mathrm{c} \rightarrow \mathrm{TS} 1 \mathrm{~cd}$ & 87 & 83 & 98 & 90 \\
\hline $2 a \rightarrow 2 b$ & -11 & -10 & -12 & -11 \\
\hline $2 b \rightarrow 2 c$ & 15 & 15 & 12 & 14 \\
\hline $2 \mathrm{a} \rightarrow 2 \mathrm{~d}+{ }^{\bullet} \mathrm{CH}\left(\mathrm{CH}_{3}\right)_{2}$ & -19 & -22 & 15 & -3 \\
\hline $2 \mathrm{a} \rightarrow \mathrm{TS} 2 \mathrm{ad}$ & 195 & 193 & 194 & 194 \\
\hline $2 \mathrm{~b} \rightarrow 2 \mathrm{f}+{ }^{\bullet} \mathrm{CH}\left(\mathrm{CH}_{3}\right)_{2}$ & 52 & 44 & 97 & 71 \\
\hline $2 \mathrm{~b} \rightarrow 2 \mathrm{e}$ & -44 & -46 & -36 & -41 \\
\hline $2 \mathrm{~b} \rightarrow \mathrm{TS} 2 \mathrm{be}$ & 76 & 77 & 75 & 76 \\
\hline $2 \mathrm{e} \rightarrow 2 \mathrm{f}+{ }^{\bullet} \mathrm{CH}\left(\mathrm{CH}_{3}\right)_{2}$ & 97 & 90 & 134 & 112 \\
\hline $2 \mathrm{e} \rightarrow \mathrm{TS} 2 \mathrm{ef}$ & 115 & 111 & 136 & 124 \\
\hline $2 \mathrm{c} \rightarrow 2 \mathrm{~h}+\mathrm{CH}_{2}=\mathrm{C}\left(\mathrm{CH}_{3}\right)_{2}$ & -26 & -31 & 28 & -1 \\
\hline $2 \mathrm{c} \rightarrow 2 \mathrm{~g}$ & -18 & -19 & -10 & -15 \\
\hline $2 \mathrm{c} \rightarrow \mathrm{TS} 2 \mathrm{cg}$ & 49 & 51 & 49 & 50 \\
\hline $2 \mathrm{~g} \rightarrow 2 \mathrm{~h}+\mathrm{CH}_{2}=\mathrm{C}\left(\mathrm{CH}_{3}\right)_{2}$ & -8 & -12 & 38 & 13 \\
\hline $2 \mathrm{~g} \rightarrow \mathrm{TS} 2 \mathrm{gh}$ & 54 & 50 & 67 & 58 \\
\hline
\end{tabular}

an units of $\mathrm{kJmol}^{-1}$ at $0 \mathrm{~K}$ including $\mathrm{B} 3 \mathrm{LYP} / 6-31(\mathrm{~d}, \mathrm{p})$ zero-point energy corrections.

$\mathrm{C}\left(\mathrm{CH}_{3}\right)_{2}$ moiety. This reaction is again endothermic and requires relatively low activation energy, $\Delta \mathrm{H}=$ $69 \mathrm{kJmol}^{-1}$ and $\mathrm{E}_{\mathrm{TS}}=90 \mathrm{kJmol}^{-1}$ for $1 \mathrm{c} \rightarrow \mathrm{TS} 1 \mathrm{~cd} \rightarrow$ 1d $+\mathrm{CH}_{2}=\mathrm{C}\left(\mathrm{CH}_{3}\right)_{2}$ (Scheme 1 ). The calculated activation energies in the systems of model 1 is consistent with the experimental observation that simple loss of odd-electron species, $\mathrm{CH}\left(\mathrm{CH}_{3}\right)_{2}$, is preferred over the loss of even-electron side chain, $\mathrm{CH}_{2}=\mathrm{C}\left(\mathrm{CH}_{3}\right)_{2}$.

Because of the multiple functions of the model 2, many different conformation isomers are possible for deamino-glycyl-N-methyl-leucinamide radicals. 2a, 2b, and $2 \mathrm{c}$ are three isomers of interest (Scheme 2). Common to all isomers, the $\mathrm{N}$-terminal $\alpha$-carbon adopts a $\mathrm{sp}^{2}$ hybridization with the unpaired electron delocalizing along the glycyl $\mathrm{C}-\mathrm{C}(\mathrm{O})-\mathrm{N} \pi$-network. The energy barriers isolating these conformers are originated from the relative orientation of the N-terminal $\mathrm{C}-\mathrm{C}(\mathrm{O})-\mathrm{N}$ and the C-terminal $\mathrm{C}(\mathrm{O})-\mathrm{N}$ conjugated systems and the relative orientation of the leucine side chain. $\mathbf{2 a}$ and $\mathbf{2} \mathbf{b}$ have a hydrogen bond bridging the interresidual amide nitrogen and the hydrogen of the C-terminal amido group, and 2c has a hydrogen bond between the interresidual amide nitrogen and the C-terminal carbonyl oxygen. $\mathbf{2 a}$ and $\mathbf{2 b}$ have different leucine side chain orientation with respect to the peptide backbone.

For the isomer $\mathbf{2 a}$, the distance between the $\mathrm{N}$ terminal $\alpha$-carbon radical and the $\beta$-carbon of the

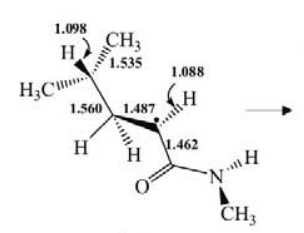

$1 \mathrm{a}$

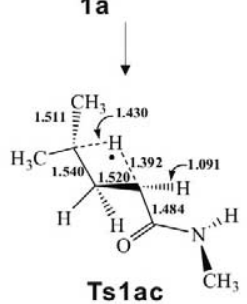

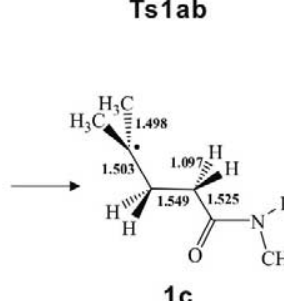

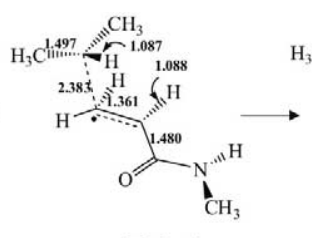

Ts1ab

$1 \mathrm{c}$

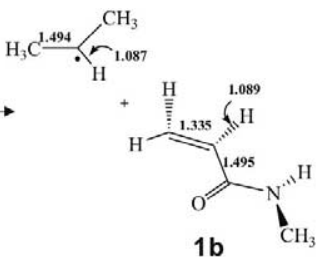

$1 \mathrm{~b}$
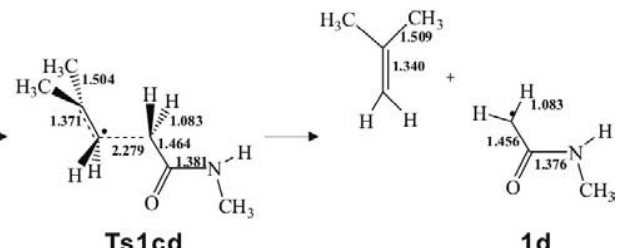

$1 d$

Scheme 1 


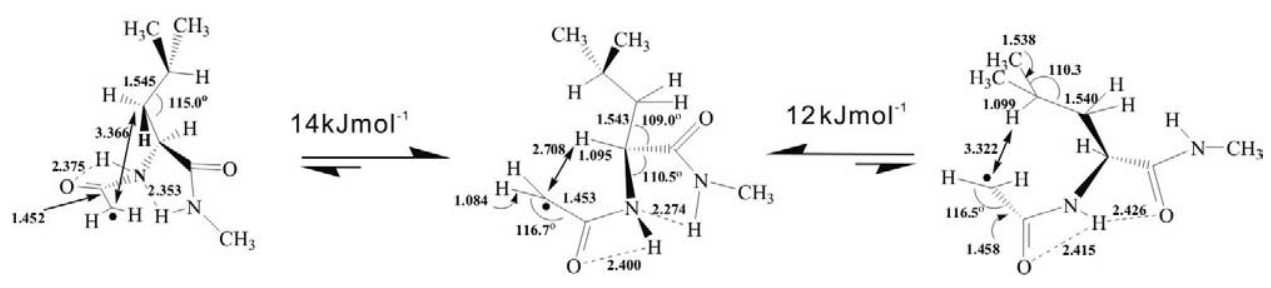

$2 a$

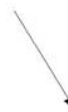

2 b

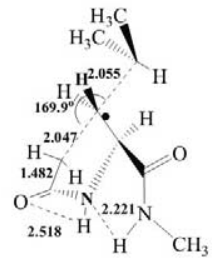

Ts2ad
$2 c$

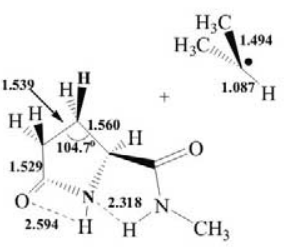

2d

Scheme 2

leucine side chain is $3.366 \AA$. To facilitate the intramolecular $S N_{2}$ reaction, the $\alpha-\beta$ carbon-carbon bond needs to rotate to a position in which the isopropyl group is pointing away from the $\alpha$-carbon radical (Scheme 2). Elimination of the isopropyl radical proceeds through a transition-state (TS2ad) in which the $\beta$-carbon is 5 -coordinated with a distorted trigonal bipyramid geometry. Moving from 2a to the transitionstate TS2ad, the distance between the N-terminal $\alpha$-carbon and the $\beta$-carbon decreases to $2.055 \AA$, whereas the bond between the $\beta$ - and $\gamma$-carbon increases to $2.046 \AA$. Attributable, presumably, to the strain of the 5 -membered ring, these carbons are not colinear and the bond angle between these atom is $169.9^{\circ}$. Although the overall reaction is slightly exothermic $\left(-3 \mathrm{kJmol}^{-1}\right)$, the reaction requires a relatively high activation energy, i.e.,
$194 \mathrm{kJmol}^{-1}$. Both the steric effect associated with the 5-coordinated carbon transition state and the strain of the 5-membered ring account for the high activation barrier.

For the isomer $\mathbf{2} \mathbf{b}$, the distance between the $\mathrm{N}$ terminal $\alpha$-carbon radical and the $\alpha$-hydrogen of the leucine side chain is only $2.708 \AA$ (Scheme 3 ). This geometry allows migration of the $\alpha$-hydrogen from the leucine side chain to the $\mathrm{N}$-terminal $\alpha$-carbon via a 5-membered ring transition-state, TS2be. Attributable, presumably, to the captodative stabilization of the $\alpha$-carbon ${ }^{\mathrm{T}}$ radical, ${ }^{\mathrm{T}}[44]^{\mathrm{T}}$ the $e^{\mathrm{T}}$ reaction ${ }^{\mathrm{T} 2} \mathrm{~b}^{\mathrm{TM} \rightarrow \mathrm{T}}{ }^{\mathrm{T}} \mathrm{TS} 2 \mathrm{be}^{\mathrm{TM} \rightarrow}{ }^{\mathrm{T}} 2 \mathrm{e}^{\mathrm{T}} \mathrm{i} \mathrm{S}$ exothermic $\left(\Delta \mathrm{H}=-41 \mathrm{kJmol}^{-1}\right)$ with a moderate activation barrier of $76 \mathrm{kJmol}^{-1}$. Elimination of the isopropyl radical proceeds via a transition-state (TS2ef) in which the $\alpha-\beta$ carbon-carbon bond is shortened to
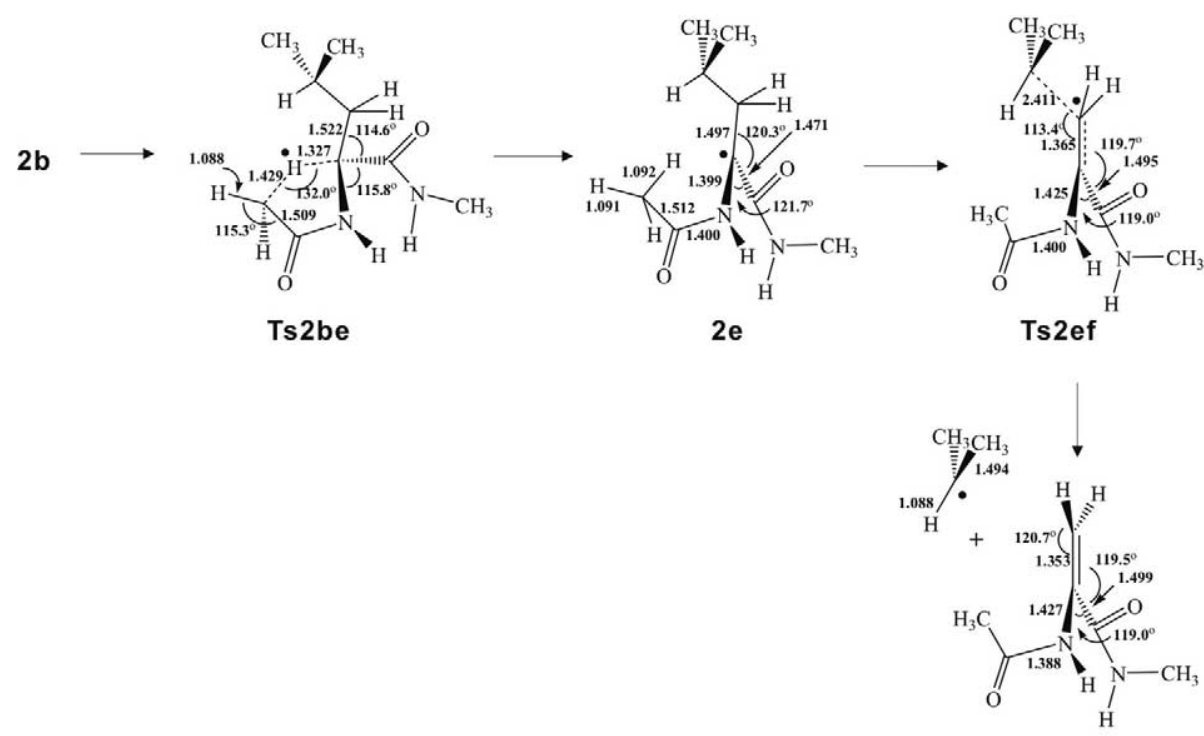

$2 f$ 


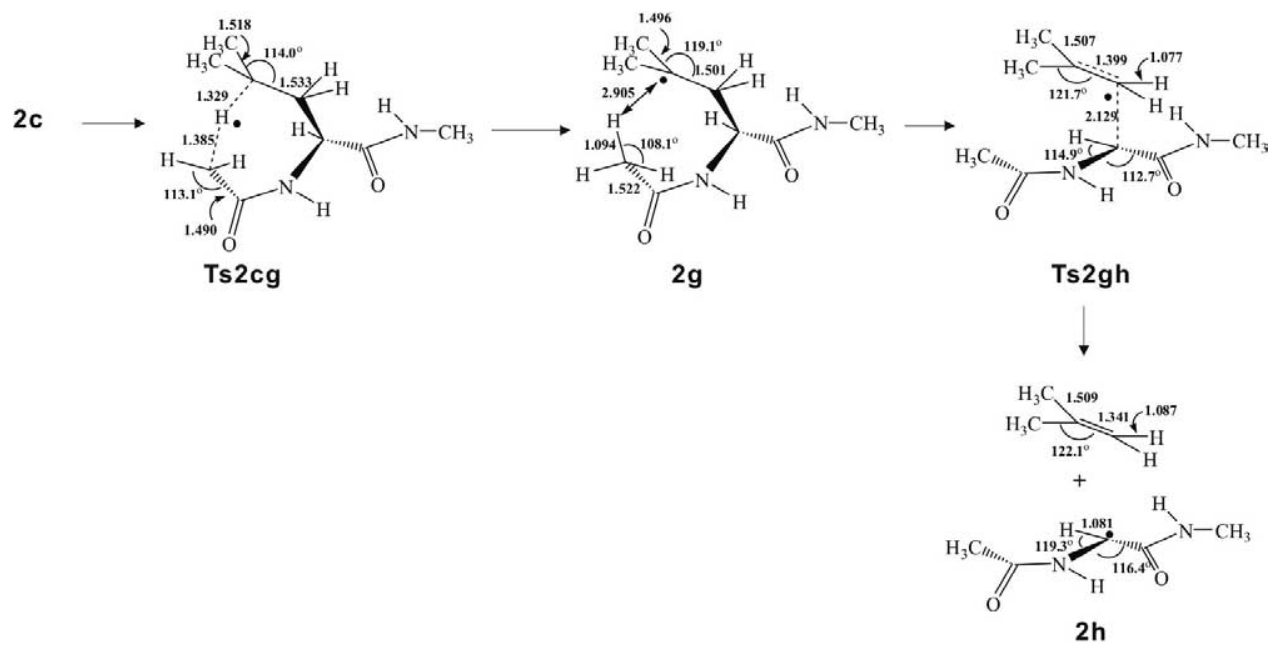

Scheme 4

$1.365 \AA$ and the $\beta-\gamma$ carbon-carbon bond is lengthened to 2.411 . Since electron density is transferred from the conjugated network involving the electron withdrawing carbonyl and amide groups to the $\gamma$-carbon, the activation barrier for this reaction is considerable, i.e., $124 \mathrm{kJmol}^{-1}$ and the reaction is endothermic, $\Delta \mathrm{H}=+112 \mathrm{kJmol}^{-1}$. Nevertheless, the overall activation barrier $\left(E_{a}\right)$ and endothermicity of the reaction are 83 and $71 \mathrm{kJmol}^{-1}$, respectively. Based on the B3-MP2 calculations, it is believed that the loss of odd electron species from $\mathrm{z} \cdot{ }^{+}$species $(n \geq 6)$ should proceed via a two-step reaction mechanism rather than the literature proposed mechanism involving the lactam formation ${ }^{\mathrm{T}}$ [37, 38 ].

For the isomer $\mathbf{2 c}$, the distance between the Nterminal $\alpha$-carbon radical and the $\gamma$-hydrogen of the leucine side chain is $3.322 \AA$ (Scheme 4). This geometry allows migration of the $\gamma$-hydrogen from the leucine side chain to the $\mathrm{N}$-terminal $\alpha$-carbon via a 7-membered ring transition-state, TS2cg. The ${ }^{\gamma} \mathrm{C}-\mathrm{H}$ bond increases from 1.099 to $1.329 \AA$; whereas the $\mathrm{N}$-terminal ${ }^{\alpha} \mathrm{C}-\mathrm{H}$ distance decreases to $1.385 \AA$. This hydrogen migration reaction is slightly exothermic $\left(\Delta \mathrm{H}=-15 \mathrm{kJmol}^{-1}\right)$ with an activation barrier of 50 $\mathrm{kJmol}^{-1}$. The second step of the reaction involves a concerted homolytic cleavage of the $\alpha-\beta$ carboncarbon bond and formation of the $\beta-\gamma$ carbon-carbon double bond. Since electron density is transferred from the $\gamma$-carbon to the conjugated network involving the electron withdrawing carbonyl and amide groups, the activation barrier for this reaction is only moderate, i.e., $58 \mathrm{kJmol}^{-1}$, and the reaction is slightly endothermic with $\Delta \mathrm{H}=+13 \mathrm{kJmol}^{-1}$. It is worthy to note that the overall reaction involves the migration of the radical site from the $\mathrm{N}$-terminal $\alpha$-carbon to the neighboring $\alpha$-carbon with the elimination of the isobutylene. Through a two-step reaction pathway, the reaction is slightly exothermic $\left(\Delta \mathrm{H}=-1 \mathrm{kJmol}^{-1}\right)$ and requires only moderate activation energy $\left(E_{a}=\right.$ $50 \mathrm{kJmol}^{-1}$ ). From an energetic point of view, this even-electron side chain loss reaction can propagate along the remaining peptide chain if other $\gamma$-hydrogen containing amino acid residues are present. This is in agreement with the literature observation that multiple loss of leucine side chains could be observed

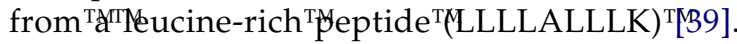

\section{Proline Cleavage}

Since proline is a cyclic amino acid, the characteristic $\mathrm{N}-\mathrm{C}_{\alpha}$ cleavage at the proline residue under low-energy electron capture dissociation conditions would not gen-

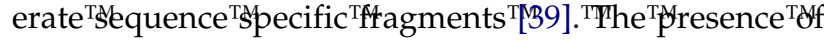
proline residue in a polypeptide could only be inferred from the masses of other fragments. In the presence study, the ECD mass spectrum of proline-containing peptide shows a distinct fragment peak at $\mathrm{m} / \mathrm{z} 441.220$. This fragment peak was not found in other peptide sequences. A plausible origin of this peak is related to the secondary fragmentation of proline residue containing $z_{n}^{+\cdot}$ fragments (i.e., $n \geq 6$ ). It is postulated that the radical at the $\mathrm{N}$-terminal $\alpha$-carbon migrates to the proline residue by abstracting the $\alpha$-hydrogen from the proline side chain. The resulting carbon radical at the $\alpha$-carbon of the proline residue is captodatively stabilized. This radical species can further decompose by cleaving the adjacent $\mathrm{N}$-terminal $\mathrm{C}-\mathrm{N}$ linkage and leading to the formation of $\mathrm{N}=\mathrm{C}$ double bond. Scheme $\mathbf{5 a}$ shows the proposed mechanism. Since the $\mathrm{C}-\mathrm{N}$ linkage at the N-terminal side of the proline is cleaved under this reaction scheme, all $z_{n}^{+\cdot}$ ion (where $n \geq 6$ ) would give the same product ion at $\mathrm{m} / \mathrm{z} 441.220$.

\section{Serine and Threonine Cleavages}

Similar to the case of proline-containing peptide, serineand threonine-containing peptides gave distinct fragment peaks at $\mathrm{m} / \mathrm{z} 416.189$ and 430.204 , respectively. These fragment peaks were not found in other peptides sequences. It is postulated that the presence of hydroxyl 
For proline-containing peptide

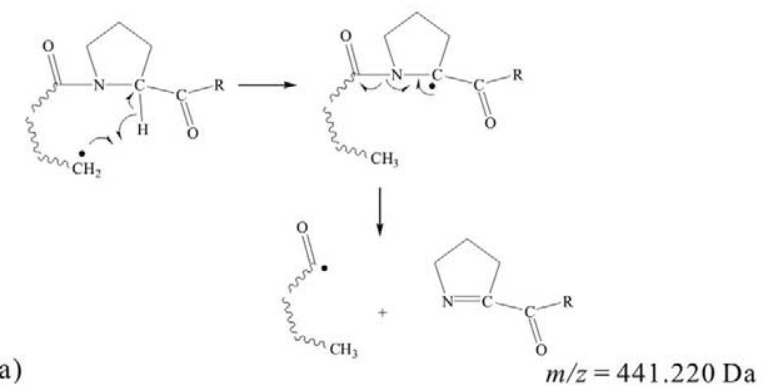

For serine- and threonine-containing peptides
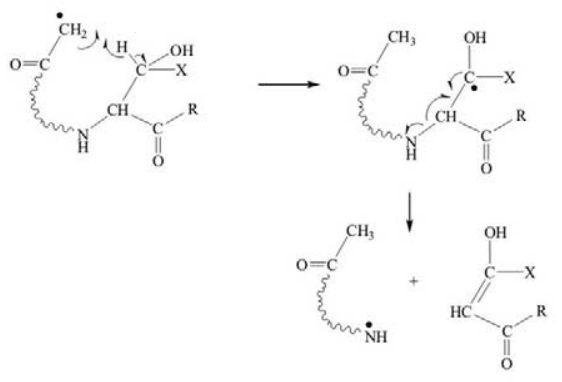

(b)

$\mathrm{X}=\mathrm{H}, m / z=416.189 \mathrm{Da}$ $\mathrm{X}=\mathrm{CH}_{3}, m / z=430.204 \mathrm{Da}$

Scheme 5

group at the $\beta$-carbon facilitates the abstraction of the $\beta$-hydrogen. The intermediate carbon radical formed at the $\beta$-carbon can be resonantly stabilized by the hydroxyl group. The intermediate decomposes by the concerted homolytic cleavage of the adjacent $\mathrm{N}-\mathrm{C}_{\alpha}$ linkage and the formation of a carbon-carbon double bond between the $\alpha$ - and $\beta$-carbon. Scheme 5b shows the proposed mechanism. Since the $\mathrm{N}-\mathrm{C}_{\alpha}$ linkage at the $\mathrm{N}$-terminal sides of the serine and threonine are cleaved under this reaction scheme, all $\mathrm{z}_{\mathrm{n}}^{+\cdot}$ ion (where $\mathrm{n} \geq 6$ ) would give the same product ions with exact masses of 416.189 and 430.204 , respectively.

\section{Peptide Sequencing Using Electron Capture Dissociation Mass Spectrometry}

Unlike the model peptides used in the present study, common peptides/proteins having multiple amino acid residues with different labile side chains might lose different side chains from a particular $\mathrm{z}^{+\cdot}$ species to form multiple secondary ion peaks. With the current efficiency of fragment ion production under ECD conditions, these ion peaks might have relatively low signal-to-noise ratios and might not be assigned. With the knowledge of the secondary fragmentation pathways described in this article, many of these minor ion peaks in typical ECD spectrum could be identified with more certainty. This is important for all levels of sequencing, including the generation of sequence-tags for library searching and complete de novo sequencing of peptides/proteins.

Another important finding in the present study is the unambiguous identification of remote secondary fragmentation from the position in which the primary $\mathrm{N}-\mathrm{C}_{\alpha}$ cleavage occurs. For instance, in the ECD spectrum of

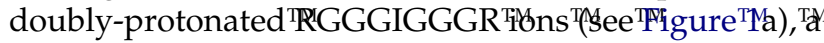
series of secondary fragment peaks corresponding to the side-chain loss of $29.040 \mathrm{Da}$ (i.e., $\cdot \mathrm{C}_{2} \mathrm{H}_{5}$ ) from all isoleucine-containing $z_{n}^{+\cdot}$ fragments (i.e., $n \geq 5$ ) was observed. Loss of ethyl radical from isoleucine-containing peptides has previously been confined to the $\mathrm{N}$ terminal side of isoleucine residue (to form the so-called $\mathrm{w}^{+}$) and its adjacent residue (to form the so-called $\mathrm{u}^{+}$)

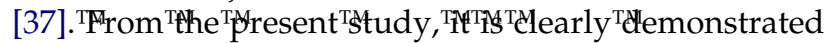
that losses of radical species from side chain would occur in any $\mathrm{z}^{+\cdot}$ fragment that is constituted by the amino acid residues with the side chain. Our observations have strong implications on the validity of using $\mathrm{w}^{+} / \mathrm{u}^{+}$species for differentiation of closely related amino acid residues, such as leucine/isoleucine and glutamine/lysine. For the differentiation of leucine/ isoleucine, Kjeldsen and Zubarev [37a] have proposed that the intensity of the identified $\mathrm{w}^{+}$should be larger than other alternative assignments (for instance, loss of 29.039 Da and 43.055 Da for leucine and isoleucine, respectively) by a factor of at least 1.5 . This criterion, though arbitrary, is found to be quite useful. From the present experimental results, the intensity of the secondary fragment derived from $\mathrm{z}_{5}^{+\cdot}$ was found to be consistently two times (or more) higher than the secondary fragments derived from $z_{n}^{+}$, where $n \geq 6$.

\section{Conclusions}

Through the study of a series of custom-designed synthetic peptides, secondary fragmentation involving losses of odd- or even-electron side chains from the labile radical fragment ions containing different amino acid residues were observed and identified. Several mechanisms have been proposed for these secondary fragmentations. With the use of leucine-based models, the energetic of these decomposition pathways were evaluated using ab initio calculations at B3-PMP2 level. In particular, two reaction pathways were proposed to account for the loss of odd-electron side chain from the labile radical fragment ions. A two-step decomposition reaction involving the abstraction of hydrogen atom from the interresidual $\alpha$-carbon and subsequent concerted $\alpha-\beta$ carbon-carbon double formation and $\beta-\gamma$ carbon-carbon bond cleavage was found to be energetically more favorable (by $\sim 111 \mathrm{kJmol}^{-1}$ ) than the literature proposed one-step reaction involving the concerted lactam formation and elimination of the oddelectron fragments. Another important finding is that side-chain loss from an amino acid residue could be initiated by remote radical centers. This observation revealed the ambiguity of identification of ile/leu (xle) residues in unknown peptides using $\mathrm{w}^{+}$fragments. 


\section{Acknowledgments}

The work described in this paper was fully supported by a grant from the Research Grants Council of the Hong Kong Special Administrative Region, China (project no. 400603). The authors thank W. K. Li, The Chinese University of Hong Kong, and P. R. Taylor, Warwick University, for their useful discussions. The authors also thank the Computer Services Center at the Chinese University of Hong Kong for its generous allocation of computer time on the Orpin and Orbit High Performance Server.

\section{References}

1. Garrison, W. M. Reaction Mechanisms in the Radiolysis of Peptides, Polypeptides, and Proteins. Chem. Rev. 1987, 87, 381-398.

2. Hawkins, C. L.; Davies, M. J. Generation and Propagation of Radical Reactions on Proteins. Biochim. Biophys. Acta 2001, 1504, 196-219.

3. Pedersen, J. Z.; Finazzi, A. A. Protein-Radical Enzymes. FEBS Lett. 1993, 325, 53-58.

4. Brush, E. J.; Lipsett, K. A.; Kozarich, J. W. Inactivation of Escherichia coli Pyruvate Formate-Lyase by Hypophosphite: Evidence for a Rate-Limiting Phosphorus-Hydrogen Bond Cleavage. Biochemistry 1988, 27, 2217-2222.

5. Licht, S.; Gerfen, G. J.; Stubbe, J. Thiyl Radicals in Ribonucleotide Reductases. Science 1996, 271, 477-481.

6. Halliwell, B.; Gutteridge, J. M. C. Free Radicals in Biology and Medicine; Oxford University Press: Oxford, 1999, pp 267-276.

7. Davis, K. J. A., Ed. In Oxidative Damage and Repair: Chemical, Biological, and Medical Aspects; Pergamon Press: New York, 1991.

8. Bacq, Z. M.; Alexander, P. Fundamentals of Radiobiology; Pergamon Press: New York, 1961, pp 115-120.

9. Cheeseman, K. H. In Immunopharmacology of Free Radical Species; Blake, D.; Winyard, P. G., Eds.; Academic Press: New York, 1995, pp 234-243.

10. Davis, K. J. Protein Damage and Degradation by Oxygen Radicals. I. General Aspects. J. Biol. Chem. 1987, 262, 98959901.

11. Neuzil, J.; Gebicki, J. M.; Stocker, R. Radical-Induced Chain Oxidation of Proteins and Its Inhibition by Antioxidants. J. Biol. Chem. 1993, 293, 601-606.

12. Stadman, E. R. Oxidation of Free Amino Acids and Amino Acid Residues in Proteins by Radiolysis and by Metal-Catalyzed Reactions. Annu. Rev. Biochem. 1993, 62, 797-821.

13. Dean, R. T.; Fu, S.; Stocker, R.; Davis, M. J. Biochemistry and Pathology of Radical-Mediated Protein Oxidation. Biochem. J. 1997, 324, 1-8.

14. Garrison, W. M. Radiation Chemistry of Amino Acids, Peptides, and Proteins in Relation to the Radiation Sterilization of High-Protein Foods. Radiat. Eff. 1981, 54, 29-39.

15. D'Arcy, J. B.; Sevilla, M. D. An Electron Spin Resonance Study of Electron Reactions with Peptides: Competitive Mechanisms: Deamination versus Protonation. Radiat. Phys. Chem. 1979, 13, 119-126.

16. Uchida, K.; Kato, Y.; Kawakishi, S. V. A Novel mechanism for Oxidative Cleavage of Propyl Peptides Induced by the Hydroxyl Radical. Biochem. Biophys. Res. Commun. 1990, 169, 265-271.

17. Zubarev, R. A.; Kelleher, N. L.; McLafferty, F. W. Electron Capture Dissociation of Multiply Charged Protein Cations. A Nonergodic Process. J. Am. Chem. Soc. 1998, 120, 3265-3266.

18. Kelleher, N. L.; Zubarev, R. A.; Bush, K.; Furie, B.; Furie, B. C.; McLafferty, F. W.; Walsh, C. T. Localization of Labile Posttranslational Modifications by Electron Capture Dissociation Mass Spectrometry. Anal. Chem. 2001, 73, 19-22.
19. Stensballe, A.; Jensen, O. N.; Olsen, J. V.; Haselmann, K. F.; Zubarev, R. A. Electron Capture Dissociation of Singly and Multiply Phosphorylated Peptides. Rapid Commun. Mass Spectrom. 2000, 14, 1793-1800.

20. Mirgorodskaya, E.; Roepstoff, P.; Zubarev, R. A. Localization of O-Glycosylation Sites in Peptides by Electron Capture Dissociation in a Fourier Transform Mass Spectrometer. Anal. Chem. 1999, 71, 4431-4436.

21. Guan, Z; Yates, N. A.; Bakhtiar, R. Detection and Characterization of Methionine Oxidation in Peptides by CollisionInduced Dissociation and Electron Capture Dissociation. J. Am. Soc. Mass Spectrom. 2003, 14, 605-613.

22. (a) Zubarev, R. A.; Horn, D. M.; Fridriksson, E. K.; Kelleher, N. L.; Kruger, N. A.; Lewis, M. A.; Carpenter, B. K.; McLafferty, F. W. Electron Capture Dissociation for Structural Characterization of Multiply Charged Protein Cations. Anal. Chem. 2000, 72, 563-573. (b) Ying, G.; Lawhorn, B. G.; El Naggar, M.; Strauss, E.; Park, J.-H.; Belgey, T. P.; McLafferty, F. W. Top Down Characterization of Large Proteins ( $45 \mathrm{kDa}$ ) by Electron Capture Dissociation Mass Spectrometry. J. Am. Chem. Soc. 2001, 123, 9792-9799.

23. Leymarie, N.; Costello, C. E.; O'Connor, P. B. Electron Capture Dissociation Initiates a Free Radical Reaction Cascade. J. Am. Chem. Soc. 2003, 125, 8949-8958.

24. Neta, P.; Huie, R. E.; Ross, A. B., Rate Constants for Reactions of Peroxyl Radicals in Fluid Solutions. J. Phys. Chem. Ref. Data 1990, 19, 715-724.

25. Lau, R. L. C.; Jiang, J.; Ng, D. K. P.; Chan, T.-W. D. Fourier Transform Ion Cyclotron Resonance Studies of Lanthanide (III) Porphyrin-Phthalocyanine Heteroleptic Sandwich Complexes by Using Electrospary Ionization. J. Am. Soc. Mass Spectrom. 1997, 8, 161-169.

26. Fong, K. W. Y.; Chan, T.-W. D. A Novel Nonmetallized Tip for Electrospray Mass Spectrometry at Nanoliter Flow Rate. J. Am. Soc. Mass. Spectrom. 1999, 10, 72-75.

27. Caravtti, P.; Allemann, M. The Infinity Cell: A New TrappedIon Cell with Radiofrequency Covered Trapping Electrodes for Fourier Transform Ion Cyclotron Resonance Mass Spectrometry. Org. Mass Spectrom. 1991, 26, 514-518.

28. Chan T.-W. D.; Ip, W. H. H. Optimization of Experimental Parameters for Electron Capture Dissociation of Peptides in a Fourier Transform Mass Spectrometer. J. Am. Soc. Mass. Spectrom. 2002, 13, 1396-1406.

30. (a) Becke, A. D. A New Mixing of Hartree-Fock and Local Density-functional Theories. J. Chem. Phys. 1993, 98, 13721377. (b) Becke, A. D. Density Functional Thermochemistry III. The Role of Exact Exchange. J. Chem. Phys. 1993, 98, 5648-5652. (c) Stephens, P. J.; Delvin, F. J.; Cabalowski, C. F.; Fisch, M. J. $\mathrm{Ab}$ Initio Calcualtion of Vibrational Absorption and Circular Dichroism Spectra Using Density Functional Force Fields. J. Phys. Chem. 1994, 98, 11623-11627.

31. Scott, A. P.; Radom, L. Harmonic Vibrational Frequencies: An Evaluation of Hartree-Fock, Moller-Plesset, Quadratic Configuration Interaction, Density Functional Theory, and Semiempirical Scale Factors. J. Phys. Chem. 1996, 100, 16502-16513.

32. (a) Turecek, F. Proton Affinity of Dimethyl Sulfoxide and Relative Stabilities of $\mathrm{C}_{2} \mathrm{H}_{6} \mathrm{OS}$ Molecules and $\mathrm{C}_{2} \mathrm{H}_{7} \mathrm{OS}^{+}$Ions. A Comparative G2(MP2) ab Initio and Density Functional Theory Study. J. Phys. Chem. A 1998, 102, 4703-4713. (b) Wolken, J. K.; Turecek, F. Heterocyclic Radicals in the Gas Phase. An Experimental and Computational Study of 3-Hydroxypyridinium Radicals and Cations. J. Am. Chem. Soc. 1999, 121, 6010-6018. (c) Polasek, M.; Turecek, F. Hydrogen Atom Adducts to Nitrobenzene: Formation of the Phenylnitronic Radical in the Gas Phase and Energetics of Wheland Intermediates. J. Am. Chem. Soc. 2000, 122, 9511-9524. 
33. (a) Brandon, C.; Tooze, J. Introduction to Protein Structure; Garland: New York, 1991 pp 9-10. (b) Mihalca, R.; Kleinnijenhuis, A. J.; McDonnell, L. A.; Heck, A. J. R.; Heeren, R. M. A. ECD at Low Temperatures Reveals Selective Dissociations. J. Am. Soc. Mass Spectrom. 2004, 15, 1869-1873.

34. Cooper, H. J.; Hudgins, R. R.; Håkansson K.; Marshall, A. G. Characterization of Amino Acid Side-Chain Losses in Electron Capture Dissociation. J. Am. Soc. Mass Spectrom. 2002, 13, 241-249.

35. (a) Haselmann, K. F.; Budnik, B. A.; Kjeldsen, F.; Polfer, N. C.; Zubarev, R. A. Can the (M-X) Region in Electron Capture Dissociation Provide Reliable Information on Amino Acid Composition of Polypeptides? Eur. J. Mass Spectrom. 2002, 8, 461-469. (b) Cooper, H. J.; Håkansson, K.; Marshall, A. G.; Hudgins, R. R.; Haselmann, K. F.; Kjeldsen, F.; Budnik, B. A.; Polfer, N. C.; Zubarev, R. A. The Diagnostic Value of Amino Acid Side-Chain Losses in Electron Capture Dissociation of Polypeptides. Comment on: "Can the (M-X) Region in Electron Capture Dissociation Provide Reliable Information on Amino Acid Composition of Polypeptides?" Eur. J. Mass Spectrom. 2003, 9, 221-222.

36. Turecek, F. N-C $\mathrm{C}_{\alpha}$ Bond Dissociation Energies and Kinetics in Amide and Peptide Radicals. Is the Dissociation a Nonergodic Process? J. Am. Chem. Soc. 2003, 125, 5954-5963.

37. (a) Kjeldsen, F; Haselmann, K. F.; Sørensen, E. S.; Zubarev, R. A. Distinguishing of Ile/Leu Amino Acid Residues in the PP3 Protein by (Hot) Electron Capture Dissociation in Fourier Transform Ion Cyclotron Resonance Mass Spectrometry. Anal. Chem. 2003, 75, 1267-1274. (b) Kjeldsen, F; Zubarev, R. A. Secondary Losses via $\gamma$-Lactam Formation in Hot Electron Capture Dissociation: A Missing Link to Complete de Novo Sequencing of Proteins? J. Am. Chem. Soc. 2003, 125, 66286629.
38. Johnson, R. S.; Martin, S. A.; Biemann, K.; Stults, J. T.; Watson J. T. Novel Fragmentation Process of Peptides by CollisionInduced Decomposition in a Tandem Mass Spectrometer: Differentiation of Leucine and Isoleucine. Anal. Chem. 1987, 59, 2621-2625.

39. Cooper, H. J.; Hudgins, R. R; Håkansson K.; Marshall, A. G. Secondary Fragmentation of Linear Peptides in Electron Capture Dissociation. Int. J. Mass Spectrom. 2003, 228, 723-728.

40. Zubarev, R. A.; Haselmann, K. F.; Budnik, B.; Kjeldsen, F.; Jensen, F.. Towards an Understanding of the Mechanism of Electron-Capture Dissociation: A Historical Perspective and Modern Ideas. Eur. J. Mass Spectrom. 2002, 8, 337-349.

41. (a) Syrstad, E. A.; Stephens, D. D.; Turecek, F. Hydrogen Atom Adducts to the Amide Bond. Generation and Energetics of Amine Radicals in the Gas Phase. J. Phys. Chem. A 2003, 107, 115-126. (b) Turecek, F.; Syrstad, E. A. Mechanism and Energetics of Intramolecular Hydrogen Transfer in Amide and peptide Radicals and Cation Radicals. J. Am. Chem. Soc. 2003, 125, 3353-3369.

42. Syrstad, E. A.; Turecek, F. Toward a General Mechanism of Electron Capture Dissociation. J. Am. Soc. Mass Spectrom. 2005, $16,208-224$.

43. Turecek, F.; Syrstad, E. A.; Seymour, J. L.; Chen X.; Yao C. Peptide Cation Radicals. A Computational Study of the Competition Between Peptide $\mathrm{N}-\mathrm{C}_{\alpha}$ Bond Cleavage and Loss of the Side Chain in the [GlyPhe-NH2 $+2 \mathrm{H}]^{+\cdot}$ Cation Radical. J. Mass Spectrom. 2003, 38, 1093-1104.

44. (a) Turecek, F.; Carpenter, F. H. Glycine Radicals in the Gas Phase. J. Chem. Soc. Perkin Trans. 2 1999, 11, 2315-2323. (b) Rauk, A.; Armstrong, D. A. Influence of $\beta$-Sheet Structure on the Susceptibility of Proteins to Backbone Oxidative Damage: Preference for ${ }^{\alpha} \mathrm{C}$-Centered Radical Formation at Glycine Residues of Antiparallel $\beta$-Sheets. J. Am. Chem. Soc. 2000, 122, 4185-4192. 